\title{
Gene expression profiling in gills of the great spider crab Hyas araneus in response to ocean acidification and warming
}

\author{
Lars Harms ${ }^{1 *}$, Stephan Frickenhaus ${ }^{2}$, Melanie Schiffer ${ }^{1}$, Felix Christopher Mark', Daniela Storch', Christoph Held ${ }^{3}$, \\ Hans-Otto Pörtner ${ }^{1}$ and Magnus Lucassen ${ }^{1}$
}

\begin{abstract}
Background: Hypercapnia and elevated temperatures resulting from climate change may have adverse consequences for many marine organisms. While diverse physiological and ecological effects have been identified, changes in those molecular mechanisms, which shape the physiological phenotype of a species and limit its capacity to compensate, remain poorly understood. Here, we use global gene expression profiling through RNA-Sequencing to study the transcriptional responses to ocean acidification and warming in gills of the boreal spider crab Hyas araneus exposed medium-term (10 weeks) to intermediate $(1,120 \mu \mathrm{atm})$ and high (1,960 $\mu \mathrm{atm}) \mathrm{PCO}_{2}$ at different temperatures $\left(5^{\circ} \mathrm{C}\right.$ and $\left.10^{\circ} \mathrm{C}\right)$.

Results: The analyses reveal shifts in steady state gene expression from control to intermediate and from intermediate to high $\mathrm{CO}_{2}$ exposures. At $5^{\circ} \mathrm{C}$ acid-base, energy metabolism and stress response related genes were upregulated at intermediate $P \mathrm{CO}_{2}$, whereas high $P \mathrm{PO}_{2}$ induced a relative reduction in expression to levels closer to controls. A similar pattern was found at elevated temperature $\left(10^{\circ} \mathrm{C}\right)$. There was a strong coordination between acid-base, metabolic and stress-related processes. Hemolymph parameters at intermediate $P \mathrm{CO}_{2}$ indicate enhanced capacity in acid-base compensation potentially supported by upregulation of a V-ATPase. The likely enhanced energy demand might be met by the upregulation of the electron transport system (ETS), but may lead to increased oxidative stress reflected in upregulated antioxidant defense transcripts. These mechanisms were attenuated by high $P \mathrm{CO}_{2}$, possibly as a result of limited acid-base compensation and metabolic down-regulation.
\end{abstract}

Conclusion: Our findings indicate a $\mathrm{PCO}_{2}$ dependent threshold beyond which compensation by acclimation fails progressively. They also indicate a limited ability of this stenoecious crustacean to compensate for the effects of ocean acidification with and without concomitant warming.

Keywords: Hyas araneus, RNA-Seq, Ocean acidification, Warming, Gene expression, Crustaceans

\section{Background}

Increasing anthropogenic emissions of $\mathrm{CO}_{2}$ induce ocean warming and acidification. These changes in environmental conditions may have adverse effects on marine organisms [1-5]. However, the responses to ocean acidification (OA) are highly variable between organisms $[4,5]$ based on the fact that various animals differ in their capacities to compensate for acid-base disturbances caused by elevated seawater $\mathrm{CO}_{2}$ and resulting blood

\footnotetext{
* Correspondence: Lars.Harms@awi.de

'Integrative Ecophysiology, Alfred Wegener Institute, Bremerhaven, Germany Full list of author information is available at the end of the article
}

hypercapnia for review see [5]. Organisms with low compensation abilities show depressed metabolism, altered energy budgets, and as a result, lower rates of growth or development [6-9]. In contrast, organisms compensating for acid-base disturbances through active ion transport, such as fish, cephalopods and some crustaceans are projected to be more tolerant towards OA $[3,10]$. In parallel to these differential capacities, sensitivities within a phylum seem to be related to differences in lifestyle and associated energy turnover [5,11]. Furthermore, species or populations from highly variable environments with natural variations in $\mathrm{PCO}_{2}$ may have 
evolved to be more tolerant than species from relatively stable environments. As an extreme example, the shallow living crab Cancer magister can compensate within $24 \mathrm{~h}$ for hypercapnia-induced acidosis, while the extracellular acidosis in the deep-sea crab Chionoecetes tanneri remains mostly uncompensated during this time [12]. However, such short-term studies have limited value if it comes to the projection of long-term ocean acidification effects.

The great spider crab Hyas araneus is an osmoconforming, slow-moving and inactive species living in relatively stable physical conditions and is thus an excellent candidate to study the medium to long-term effects of abiotic stressors. A number of physiological studies have already investigated the effects of elevated seawater $P \mathrm{CO}_{2}$ on this species: $\mathrm{CO}_{2}$ induced decreases in growth rates and fitness of larvae were demonstrated in a North Sea population, whereas an Arctic population seemed more sensitive towards thermal stress [13]. In the Spitsbergen population elevated seawater $P^{2} \mathrm{CO}_{2}(1,100 \mu \mathrm{atm})$ caused an increase in metabolic rate during larval development pointing to higher metabolic costs [14]. Adult $H$. araneus became more heat intolerant under elevated $\mathrm{CO}_{2}$ with potential consequences for biogeographical distribution [15]. In the Arctic population synergistic effects of increased temperature and $P \mathrm{PO}_{2}$ adversely influenced the capacities for activity associated with disturbances in acid-base status [16].

To understand organismal sensitivities and tolerancelimits to OA with and without concomitant warming it is important to identify and differentiate between the mechanisms that shape an organism's capacity to cope with the projected changes. At the whole organism level, crustaceans are impacted by OA with and without concomitant warming with effects ranging from changes in acid-base homeostasis [12,16,17], metabolism [9,18,19], growth $[7,13,20,21]$, to development $[13,14,22,23]$ and even survival $[21,24]$. These processes are highly interdependent. While active acid-base regulation is an energy-consuming process [25], eventually leading to enhanced metabolic requirements [26], uncompensated extracellular $\mathrm{pH}$ can elicit metabolic depression [27] via effects on transmembrane ion exchange [25]. Furthermore, low pH can trigger a decrease in protein synthesis [28]; this may result in reduction of growth under hypercapnic conditions [6]. These previous studies provide us with important insights into the mechanistic background of responses to ongoing $\mathrm{OA}$ and warming, but also highlight the complexity of the processes involved. To elaborate the sensitivities and potential tolerance limits further, it is important to investigate the key regulatory mechanisms shaping affected processes and the tradeoffs between them.

A transcriptomic approach makes it possible to simultaneously investigate the genetic response of a wide range of cellular processes, and thus to identify the early responses to environmental changes [29]. Gene expression analyses can be used to characterize the molecular phenotype and the cellular changes that underpin physiological responses. They can also be used to uncover molecular mechanisms that might define physiological plasticity. Transcriptomic analysis can further reveal the connections between response mechanisms to environmental changes such as OA or temperature that may otherwise be overlooked [30]. Due to technological advances in recent years, analyses of the whole transcriptome have become increasingly attractive to study nonmodel (marine) organisms, and their molecular responses to a variety of environmental changes such as warming [31,32], salinity fluctuations [33], hypoxia [34,35] or OA $[29,36,37]$ in marine organisms.

In the present study, we used gene expression profiling to explore the molecular response in gills of $H$. araneus exposed to hypercapnia at different temperatures. In marine crustaceans, gills are the first line of defence against acid-base disturbances of body fluids and thus the most important regulatory tissue for $\mathrm{CO}_{2}$ induced acidification of the hemolymph $[38,39]$. We used a quantitative transcriptomic approach based on direct cDNA sequencing using high-throughput Illumina sequencing [40]. Since the present study focuses on the mechanisms involved and the potential sensitivity of $H$. araneus to climate changes, we selected $\mathrm{CO}_{2}$ concentrations projected for the year 2100 and 2300 by the Intergovernmental Panel on Climate Change (IPCC) as well as two different temperatures $\left(5^{\circ} \mathrm{C}\right.$ as the summer control temperature for the Arctic population and $10^{\circ} \mathrm{C}$ as the median habitat temperature of the species considering the whole distribution range. This study provides comprehensive insights into the transcriptional changes involved in the responses to warming and $\mathrm{OA}$.

\section{Methods}

Animals, experimental treatments and tissue sampling

Adult specimens of the Arctic spider crab $H$. araneus (Linnaeus 1758) were collected by scientific divers in May 2009 in Kongsfjord at the west coast of Spitsbergen at 7-12 m depth (N 78 $58.635^{\prime}$; E 11 $\left.29.454^{\prime}\right)$ and transferred to the Alfred Wegener Institute, Bremerhaven, Germany. Animals were maintained at $5^{\circ} \mathrm{C}$ in flow through aquaria with natural seawater prior to experimentation. During this period, seawater was aerated with ambient air and animals were fed ad libitum twice per week with frozen mussels and cockles (Mytilus edulis and Cerastoderma edule).

For the medium-term experiment, male spider crabs with a carapace width of 26 to $42 \mathrm{~mm}$ were divided into six groups and each group was randomly assigned to the different treatments. Animals were exposed to three different $\mathrm{CO}_{2}$ concentrations $(390 \mu \mathrm{atm}$ as control, 
1,120 $\mu \mathrm{atm}$ as intermediate concentration and 1,960 $\mu \mathrm{atm}$ as high $\mathrm{CO}_{2}$ treatment) and two different temperatures $\left(5^{\circ} \mathrm{C}\right.$ as control and $10^{\circ} \mathrm{C}$ as elevated temperature) for 10 weeks (Figure 1). For each treatment, 5-7 animals were individually placed in 21 wide-mouth containers (Kautex, Bonn, Germany).

Experiments were carried out in recirculating seawater $\mathrm{CO}_{2}$ manipulation systems of 1 cubic meter volume each. Seawater of the storage tank was pumped to a header tank at a rate of $20 \mathrm{l} \mathrm{min}^{-1}$, which supplied the wide-mouth container by gravity feed at a flow rate of $200 \mathrm{ml} \mathrm{min}^{-1}$. Water of experimental containers was retained in a collection tank and pumped back to the storage tank at a flow rate of $201 \mathrm{~min}^{-1}$. Ambient air temperature in the experimental rooms was thermostated to keep water temperature constant. Seawater $\mathrm{CO}_{2}$ manipulation was accomplished by constantly aerating the storage and header tanks with a defined air $/ \mathrm{CO}_{2}$ mixture using an automatic mass flow controller (HTK 6 channel, HTK Hamburg GmbH, Germany). A light-dark cycle of 12:12 h was established. Water was partly changed every week by refilling the storage tank with pre-equilibrated seawater $\left(\mathrm{PCO}_{2}\right.$ and temperature). Experimental animals were fed once a week ad libitum with frozen mussels (C. edule).

To monitor water physicochemistry, seawater samples were collected in airtight glass vials to prevent exchange with the atmosphere, and total dissolved carbon (DIC) concentration was immediately measured with a Seal QuAAtro SFA Analyzer (Seal Analytical, Mequon, United States of America). Temperature, salinity and $\mathrm{pH}$ were measured at the time of collection and, together with DIC, used to calculate the $\mathrm{PCO}_{2}$ in seawater using CO2SYS [41]. Seawater $\mathrm{pH}$ was measured using a $\mathrm{pH}$ electrode (ProfiLine pH 3310, WTW Wissenschaftlich-Technische Werkstätten $\mathrm{GmbH}$, Weilheim, Germany) calibrated at the respective temperature with National Institute of Standards and Technology (NIST) standard pH buffer and salinity with a conductivity meter (ProfiLine Cond 1970i, WTW Wissenschaftlich-Technische Werkstätten GmbH, Weilheim, Germany). For CO2SYS, NBS (NIST) scale of seawater $\mathrm{pH}$ and constants of Mehrbach et al. [41] refitted by Dickson and Millero [41] were used. A summary of water physicochemistry data is given in Table 1 .

After experimental exposure, all 6 gill pairs were collected from 5-7 animals in each treatment. Tissue samples were immediately frozen in liquid nitrogen and stored at $-80^{\circ} \mathrm{C}$ until usage.

\section{Hemolymph sampling and measurements}

Directly before tissue sampling, around $1 \mathrm{ml}$ of hemolymph was extracted at the coxa of the third walking leg using a $1 \mathrm{ml}$ sterile syringe (Henke-Sass, Wolf GmbH, Tuttlingen, Germany). Hemolymph was immediately transferred to a $1.5 \mathrm{ml}$ tube (AG Eppendorf, Hamburg, Germany), placed in a thermostatted water bath and $\mathrm{pH}$ was measured at acclimation temperature using a pH microelectrode (PHM 93 Reference pH meter, Radiometer, Copenhagen, Denmark; InLab Micro, Mettler Toledo $\mathrm{GmbH}$, Germany). The $\mathrm{pH}$ meter was calibrated at the respective temperature with NIST standard $\mathrm{pH}$ buffer. A hemolymph subsample was withdrawn using a gastight $200 \mu \mathrm{l}$ syringe (Hamilton Company, Reno, United States of America) and total dissolved inorganic carbon $\left(\mathrm{CCO}_{2}\right)$ of extracellular fluid was analysed according to the modified gas chromatographic method [42,43]. Extracellular fluid was injected in gas tight glass vials containing $3 \mathrm{ml}$ of air equilibrated $0.1 \mathrm{M}$ hydrogen chloride $(\mathrm{HCl})$ and analysed by gas chromatography in an Agilent $6890 \mathrm{~N}$ GC System (Agilent Technologies, Santa Clara, United States of America). The bicarbonate $\left(\mathrm{HCO}_{3}^{-}\right)$concentration of the extracellular fluid was calculated from $\mathrm{CCO}_{2}$ and $\mathrm{pH}$ using equations derived from the Henderson-Hasselbalch equation. $\mathrm{PCO}_{2}$ was calculated as $\mathrm{PCO}_{2}=\mathrm{CCO}_{2} *\left(10^{\mathrm{ph}-\mathrm{pkIII}} * \alpha \mathrm{CO}_{2}+\alpha \mathrm{CO}_{2}\right)^{-} 1$ and $\mathrm{HCO}_{3}{ }^{-}$

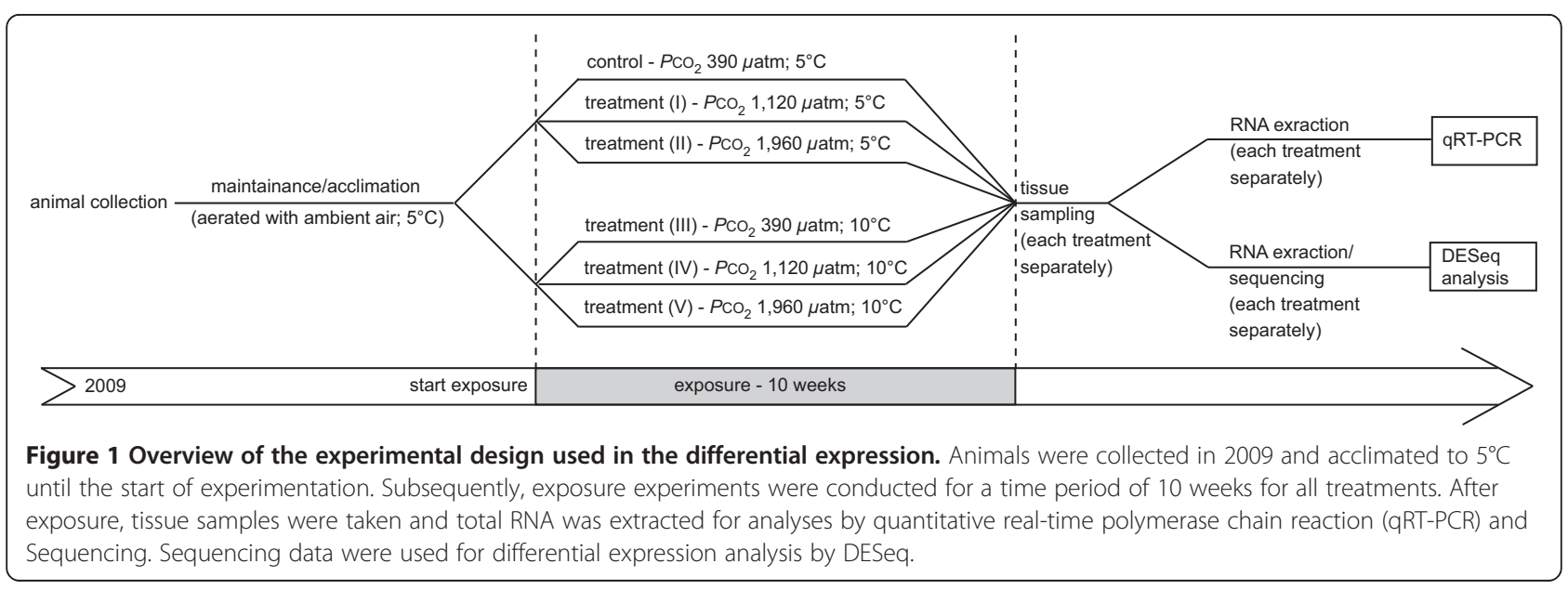


Table 1 Summary of the seawater physiochemical conditions during experiments with Hyas araneus

\begin{tabular}{lllllll}
\hline Parameter & Control & Treatment (I) & Treatment (II) & Treatment (III) & Treatment (IV) & Treatment (V) \\
\hline Temperature $\left({ }^{\circ} \mathrm{C}\right)$ & $5.3 \pm 0.2$ & $4.2 \pm 0.2$ & $4.5 \pm 0.2$ & $9.9 \pm 0.2$ & $9.7 \pm 0.3$ & $9.8 \pm 0.2$ \\
Salinity (\%o) & $32.1 \pm 0.7$ & $32.2 \pm 0.7$ & $32.2 \pm 0.6$ & $33.6 \pm 0.4$ & $33.5 \pm 0.4$ & $33.6 \pm 0.3$ \\
$\mathrm{pH}(\mathrm{NBS} \mathrm{scale)}$ & $8.15 \pm 0.03$ & $7.81 \pm 0.04$ & $7.55 \pm 0.06$ & $8.22 \pm 0.04$ & $7.85 \pm 0.04$ & $7.54 \pm 0.05$ \\
$\mathrm{DIC}\left(\mathrm{mmol} \mathrm{kg}{ }^{-1}\right)$ & $2,366 \pm 42$ & $2,436 \pm 14$ & $2,520 \pm 39$ & $2,295 \pm 28$ & $2,395 \pm 14$ & $2,488 \pm 22$ \\
$P \mathrm{CO}_{2}(\mu \mathrm{\mu atm})$ & $441 \pm 35$ & $991 \pm 96$ & $1,878 \pm 246$ & $366 \pm 30$ & $942 \pm 59$ & $2,015 \pm 147$ \\
Total alkalinity $\left(\mathrm{mmol} \mathrm{kg}{ }^{-1}\right)$ & $2,479 \pm 13$ & $2,479 \pm 14$ & $2,491 \pm 14$ & $2,484 \pm 10$ & $2,469 \pm 13$ & $2,473 \pm 15$ \\
\hline
\end{tabular}

Temperature, Salinity, $\mathrm{pH}$ and dissolved inorganic carbon $(\mathrm{DIC})$ were measured and partial pressure of $\mathrm{CO}_{2}\left(P \mathrm{CO}_{2}\right)$ and total alkalinity were calculated using CO2SYS [41]. Data are mean $\pm S D$ with $\mathrm{N}=24\left(5^{\circ} \mathrm{C}\right), \mathrm{N}=16-20\left(10^{\circ} \mathrm{C}\right)$.

as $\mathrm{HCO}_{3}{ }^{-}=\mathrm{CCO}_{2}-\alpha \mathrm{CO}_{2} * \mathrm{PCO}_{2}$, with $\mathrm{CCO}_{2}$ being the total $\mathrm{CO}_{2}$ concentration in $\mathrm{mM}, \alpha \mathrm{CO}_{2}$ the physical solubility of $\mathrm{CO}_{2}, \mathrm{PCO}_{2}$ the partial pressure of $\mathrm{CO}_{2}$ in $\mathrm{kPa}$ and $\mathrm{pK}$ the apparent dissociation constant of the $\mathrm{CO}_{2}$ /apparent $\mathrm{HCO}_{3}{ }^{-}$system. $\alpha \mathrm{CO}_{2}$ and $\mathrm{pK}$ were calculated according to Pörtner et al. [44]. Raw data of hemolymph sampling and measurements are available at http://doi.org/10.1594/PANGAEA.833705.

\section{RNA extraction and sequencing}

Total tissue RNA of gills was extracted using the RNeasy Mini Kit according to the Purification of Total RNA from Animal Tissue protocol (QIAGEN, Hilden, Germany). RNA quantities were determined by a NanoDrop 2000c spectrometer (PeqLab, Erlangen, Germany), and RNA was analysed for quality by microfluidic electrophoresis in an Agilent 2100 Bioanalyzer (Agilent Technologies, Santa Clara, United States of America). Total RNA from all gill pairs of 4 animals was pooled for each treatment, and used for library constructions and sequencing by GATC Biotech (Konstanz, Germany). The cDNA libraries for each treatment were constructed according to the SMART protocol for Illumina sequencing (Clontech, Mountain View, USA) and after adapter ligation pooled into two samples. To obtain appropriate deep sequencing results, samples were sequenced at least twice. Illumina sequencing was performed on a HiSeq 2000 Sequencer by GATC Biotech (Konstanz, Germany). Raw reads were quality controlled by FastQC (Babraham Institute, Cambridge, UK) and cleaned using the FastX-Toolkit (Hannon Lab - Cold Spring Harbor Laboratory, New York, USA). Quality control and trimming was performed using the following parameters: Minimum quality score of 20, minimum percentage of bases within the quality score of 90 and a minimum length of 25 bases. The cleaned raw data of the Illumina sequencing were deposited in the European Nucleotide Archive (ENA) at the European Molecular Biological Laboratory - European Bioinformatics Institute (EMBL-EBI) (http://www.ebi.ac.uk/ena/data/ view/ERP002128). A summary of the cleaned sequencing results for all samples is given in Additional file 1: Table S1.

\section{Mapping and identification of differentially expressed genes}

Short reads of each sample were separately aligned against the annotated $H$. araneus transcriptome [40], using the Burrows-Wheeler Aligner (BWA) (version 0.5.9) with default parameters [45]. Obtained files were processed into bam files for further analysis, using SAMTools (version 0.1.18) [46]. An overview of the mapping and efficiency is described in Additional file 1: Table S1. Differential expression analysis was conducted with the R statistic software [47]. Read counts were summed up for all sequencing runs of each sample and used for the differential expression analysis without biological replicates. Differential expression of genes was evaluated using a test based on the negative binomial distribution as integrated in the Bioconductor $\mathrm{R}$ package DESeq [48], with a standard level of $p \leq 0.05$ indicating significance. Control (control $\mathrm{PCO}_{2}$ /control temperature) was compared to five treatments: (I) elevated temperature; (II) intermediate $\mathrm{PCO}_{2}$ at control temperature; (III) high $P \mathrm{O}_{2}$ at control temperature (IV) intermediate $P \mathrm{PO}_{2}$ at elevated temperature; (V) high $\mathrm{PCO}_{2}$ at elevated temperature. The previously annotated transcriptome made a Gene Ontology enrichment analysis possible to test for particular affected terms, using Fisher's exact test $(F D R \leq 0.05)$ as implemented in the Blast2GO software (version 2.6.0) [49,50]. All subsets of significantly regulated genes identified by the binominal distribution test were tested against the full set of annotated sequences of the $H$. araneus transcriptome. To cut down on redundancy, GO terms were summarized into a more representative subset of terms using the web-based clustering tool REVIGO [51].

\section{Validation by quantitative real-time polymerase chain reaction (qRT-PCR)}

A set of transcript sequences known to be involved in acid-base regulation and/or transcripts that showed differential expression in one or more treatments was selected for validation of RNA-Seq results. Primers were designed using the PrimerExpress software (version 3.0) (Applied Biosystems, Darmstadt, Germany) with the 
Taq-Man MGB Quantification method and default parameters (Additional file 2: Table S2). Primer specificity was given by using sequences of the annotated $H$. araneus transcriptome [40]. All primer pairs were tested for performance and efficiency across a series of cDNA dilutions (1:20; 1:40; 1: 100; 1:200; 1:1000; 1:2000). Primers used displayed a suitable per cycle amplification rate, with an efficiency $(E)$ of $2.0 \pm 0.1$ and $R^{2}>0.98$. Efficiency was calculated as $E=10^{(-1 / \mathrm{S})}$, with s being the slope of linear regression.

Total RNA was extracted from gills as described above. Ten micrograms of total RNA per sample was treated with DNAse for DNA digestion using the Turbo DNA-free kit (Ambion, Darmstadt, Germany) and $0.4 \mu \mathrm{g}$ DNA free RNA was transcribed into cDNA with the High-Capacity cDNA Reverse Transcription kit (Applied Biosystems, Darmstadt, Germany). Real-time PCR was performed on a 7500 Real-time PCR System (Applied Biosystems, Darmstadt, Germany) and SYBR ${ }^{\circ}$ Green PCR master mix (Applied Biosystems, Darmstadt, Germany). All genes were finally analysed in a 40-fold dilution and amplified with $300 \mathrm{nM}$ of primer. To verify the amplification specificity of fragments a melting curve analysis was performed for each reaction.

Gene expression calculation was based on the $\mathrm{C}_{\mathrm{T}^{-}}$ threshold. Absolute mRNA quantities were calculated as $Q_{\mathrm{X}}=E^{(\mathrm{CT})}$ and normalized with the formula $Q_{\mathrm{N}(\mathrm{X})}=$ $Q_{\mathrm{X}} / Q_{\mathrm{X}(\mathrm{HK})}$, with $Q_{\mathrm{X}(\mathrm{HK})}$ being the absolute mRNA quantity of the housekeeping gene sodium bicarbonate cotransporter (NBC). The housekeeping gene was determined using geNorm implemented in the software qbasePlus (version 2.1) (Biogazelle, Zwijnaarde, Belgium) with a relative expression stability of $M \leq 0.42$ (high reference stability is given at an average geNorm of $M \leq 0.5)$. To ensure consistency with the differential expression results of the DESeq analysis, gene expression results of the qRTPCR were calculated as $\log _{2}$ fold change $\left(\log _{2} \mathrm{FC}\right)$ of mean normalized quantities of treatment and control.

\section{Statistics}

To identify significant differences in the sum of all significantly up- and down-regulated transcripts between treatments, significantly changed transcripts in one or more treatment, identified by the DESeq analysis, were transformed into a matrix with $1=$ significantly upregulated, $-1=$ significantly down-regulated and $0=$ not significantly regulated transcript. Treatments were analysed for statistical differences applying the Wilcoxon matched pairs test as implemented in SigmaPlot (Version 12.0, Systat Software Inc., San Jose, USA) with $p<0.05$. Data from each treatment were tested against each other.

The correlation between the differential expression results of the DESeq analysis and the corresponding gene expression results of the qRT-PCR was determined by Pearson Correlation as implemented in SigmaPlot 12.0 (Systat Software Inc., San Jose, USA).

A one-way ANOVA was used to identify the effect of seawater $\mathrm{PCO}_{2}$ on hemolymph $\mathrm{pH}$ and bicarbonate $\left(\mathrm{HCO}_{3}{ }^{-}\right)$. Data obtained under various $\mathrm{PCO}_{2}$ levels were tested against each other for each temperature separately. A Holm Sidak test for multiple comparisons was used for a posteriori analyses. Tests were performed in SigmaPlot (Version 12.0, Systat Software Inc., San Jose, United States of America) with $p<0.05$ indicating significant differences.

\section{Results and discussion}

A total of 55 million reads (56\%) from initial Illumina sequencing passed the quality filter and was used for the differential expression analysis. After processing, an average of 9.2 million high quality reads were produced for each sample from 2-3 sequencing runs per sample (Additional file 1: Table S1). To obtain the differential expression of each gene, high quality reads were aligned on the $H$. araneus transcriptome [40]. An average of 5.2 million reads for each sample produced distinct alignments. The alignment process yielded an average efficiency of $56 \%$ for the high quality reads (Additional file 1 : Table S1). The achieved mapping efficiency is actually higher than in a comparable study of a non-model organism, which used an analogous approach for differential expression analysis (41\% efficiency) [52]. Furthermore, $96.5 \%$ of all transcript sequences in the $H$. araneus transcriptome were detected in the RNA-Seq data. However, the occurrence of a large amount of unmapped reads might result from sequencing errors, repetitive sequences or inadequate quality filtering of the Illumina reads. Furthermore, it has to be considered that transcripts supported by only a small number of aligned reads $(\leq 10)$ may reflect incompletely assembled transcripts in the reference. Those poorly supported transcript sequences were excluded from the subsequent analysis, and a final test-set of 16,201 transcripts sequences was used for the differential expression analysis. As there were no biological replicates, it has to be considered that the variance for genes can only be estimated by comparing the mean-variance relationship between samples/treatments, as if they were replicates, resulting in an overestimation of the variance and thus make this approach more conservative. Furthermore, expression levels of stable and highly expressed genes, based on the RNA-Seq data, were analysed by quantitative real-time PCR (qRT-PCR) confirming the RNA-Seq methodology used in this study (Additional file 3: Figure S1 and Additional file 4: Figure S2).

We could identify 864 (5.3\%) out of the 16,202 tested transcripts to be differentially expressed after medium-term (10 weeks) exposure to the abiotic effectors (Additional file 5: Table S3). Out of these differentially 
expressed genes (DEG) $40.0 \%$ and $31.3 \%$ were differentially expressed under intermediate $\mathrm{CO}_{2}$ (treatment I) and high $\mathrm{CO}_{2}$ (treatment II; Additional file 6: Figure S3A, B), respectively. For the high temperature (treatment III), $41.0 \%$ showed significantly different expression levels (Additional file 6: Figure S3C). The combination of factors intermediate $\mathrm{CO}_{2}$ (treatment IV) and high $\mathrm{CO}_{2}$ (treatment $\mathrm{V}$ ) with elevated temperature revealed $38.7 \%$ and $29.4 \%$ DEG, respectively (Additional file 6: Figure S3D, E). While the total amount of significant DEGs was similar in all treatments, individual genes displayed large differences in up- or down-regulation (Figure 2). Intermediate $\mathrm{CO}_{2}$ (I) led to strongly up-regulated transcript levels, while high temperature (III) caused strong down-regulation.

These general results, especially the strong up-regulation of gene expression under intermediate $\mathrm{CO}_{2}$ (I), suggest that the regulatory capacity is high at moderately elevated $\mathrm{PCO}_{2}$ in adult $\mathrm{H}$. araneus but reduced at higher $\mathrm{CO}_{2}$ levels. Up-regulation was also reduced at intermediate $\mathrm{CO}_{2}$ when combined with elevated temperature (IV) rather than at control temperature. Down-regulation in DEG predominated under warming alone (treatment III, high temperature) when compared to control temperature (I). 137 of the 177 genes that displayed significantly changed transcripts in the intermediate $\mathrm{CO}_{2}$ /elevated temperature treatment (IV) were also differentially expressed in the high temperature treatment (III) supporting a strong temperature-dependent response, in

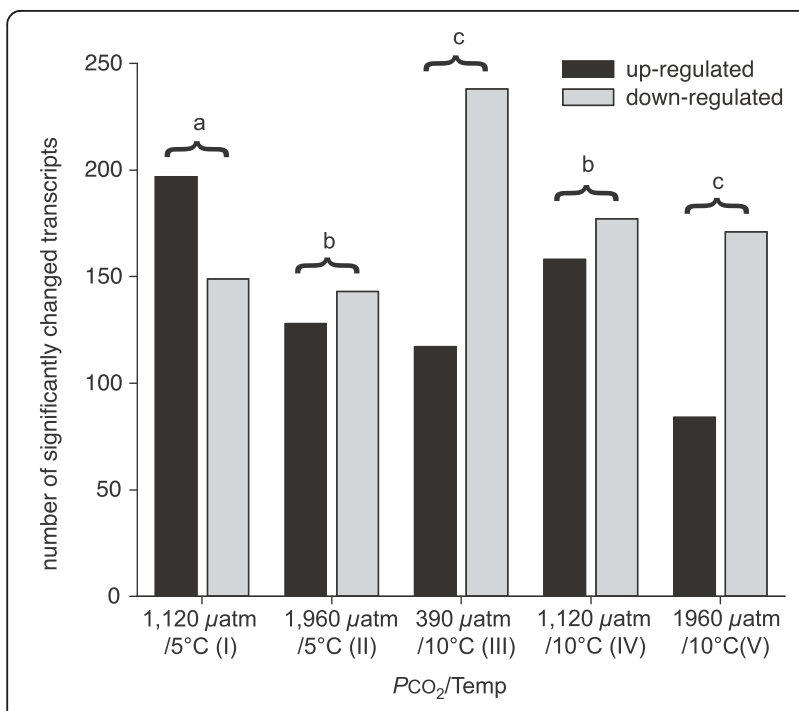

Figure 2 Differences in the sum of all significantly regulated transcripts of Hyas araneus after exposure experiments. For each treatment, up- and down-regulated transcripts were counted and represented as bars (black bars = up-regulated; grey bars = down-regulated). Treatments were tested for statistical differences using the Wilcoxon signed rank test $(p<0.05)$. Letters denote the significant differences. Differing letters indicate significant differences; identical letters indicate no significant difference. line with the hypothesis that temperature affects most biochemical processes. Faced with a long-term temperature change, ectothermal organisms retain physiological homeostasis by several acclimation strategies, which can be of quantitative, qualitative or modifying nature [53]. The enhanced down-regulation seen in the high temperature treatments suggest that $H$. araneus may adopt a quantitative strategy to maintain physiological rates by downregulating the concentrations of enzymes between 5 and $10^{\circ} \mathrm{C}[54]$.

To identify processes actually responding to elevated $\mathrm{PCO}_{2}$ and temperature, a first analysis was carried out using gene ontology (GO) terms. The set of GO-annotated differentially expressed genes was statistically tested for the over- and underrepresentation of GO terms to identify molecular functions, cellular components and biological processes affected most by the experimental treatments (Additional file 7: Table S4). The GO enrichment analysis revealed a variety of significantly over-represented GO terms that can primarily be summarized underneath the more generic categories 'metabolism' and 'cell structure'. 23 and 25 over-represented GO terms, respectively, could be associated with these categories. It is important to mention that both intermediate $\mathrm{CO}_{2}$ treatments (I, IV) constitute $57 \%$ and $27 \%$ of the over-represented GO terms, respectively, representing compensation mechanisms mentioned above. The only over-represented GO term under high $\mathrm{CO}_{2}$, trehalose metabolic process, was evaluated for the down-regulated genes of the combined stress treatment $(\mathrm{V})$. The fact that it was over-represented in all treatments indicates that enhanced expression of trehalose metabolism can be rated as a unifying response to both elevated $\mathrm{CO}_{2}$ and elevated temperature.

Within the 'cell structure' related GO-terms, intermediate $\mathrm{CO}_{2}$ (I, IV) led to significant up-regulation of genes concerning cell surface, extracellular matrix, structural molecule activity or brush border membrane, suggesting a structural modification of the gills. Some GO terms were found underrepresented at high temperature and in combined, intermediate $\mathrm{CO}_{2}$ and high temperature treatments (III, IV), and are assigned mainly to intracellular structures such as organelles. The over-representation of 'cell structure' related GO terms suggests that gill epithelial structure is adjusted in response to $\mathrm{PCO}_{2}$ disturbances. Gills are the principal organs for gas exchange and, together with the excretory organs, responsible for osmotic and ionic regulation in crustaceans [55]. As passive ion transport is influenced by the conductivity of gill epithelia [56], their structural modification might lead to a change in conductivity and would change the diffusion rate of ions. Structural changes were in fact identified in gills of Carcinus maenas during salinity exposure, with a modification of the apical plasma membrane system and an 
enlargement of the subcuticular compartment [57]. As environmental hypercapnia and salinity changes can cause similar mechanistic responses [39], similar transcriptomic modifications may occur. This is supported by an overrepresentation of the $\mathrm{GO}$ term response to salt stress in the intermediate $\mathrm{CO}_{2}$ treatment (I).

Although a GO enrichment analysis offers initial insights into processes affected by hypercapnia exposure and elevated temperature, a strong bias exists towards conserved and well-characterized processes, functions and cellular components in model organisms. This bias particularly applies to $H$. araneus, with a lack of GO annotation for about $76 \%$ of the transcripts. Additionally, many genes are grouped into more than one GO term depending on their resolution and are thus difficult to interpret. In light of these contraints, GO analysis can only provide a general overview of possibly affected processes and make a more detailed look indispensible.

For a more comprehensive understanding of the mechanisms responding to $\mathrm{PCO}_{2}$ and temperature changes, we performed a second analysis. Here, all genes included in the most affected categories 'metabolism' and 'structural modification', identified by the GO enrichment analysis, were considered. Additionally, we integrated all genes related to 'acid-base and ion regulation' and 'response to stress' into our analysis, as adjustments in these mechanisms are likely relevant in shaping resistance to hypercapnia exposure or heat stress.

For the interpretation of transcriptomic results, it has to be considered that expression profiles represent one regulatory level in the response to environmental changes and thus do not necessarily reflect the changes of other regulatory levels, e.g. protein abundances and activities. At least $25 \%$ of the proteome cannot be covered by gene expression profiling [30]. However, there was a positive correlation between transcription and translation in $87 \%$ of genes that changed $\geq$ twofold in living cells of yeast strains [58]. Certainly, a lower correlation has to be considered for more complex organisms, however an additional proteomics study on $H$. araneus revealed a comparable correlation between gene expression and protein abundance of $\sim 70 \%$ for the intermediate treatment at $5^{\circ} \mathrm{C}$ (unpublished). A transcriptomic approach can provide first insights into the regulatory processes responding to environmental changes such as OA or temperature.

\section{Response of specific groups Acid-base regulation}

The extracellular $\mathrm{pH}\left(\mathrm{pH}_{\mathrm{e}}\right)$ measured in the hemolymph of adult $H$. araneus showed partial compensation under intermediate $\mathrm{CO}_{2}$ levels (I, IV) involving an increase in bicarbonate $\left(\mathrm{HCO}_{3}^{-}\right)$concentration (Figure 3A,B). Under high $\mathrm{CO}_{2}$ (II, V), reduction in $\mathrm{pH}_{\mathrm{e}}$ was greater and the increase in $\mathrm{HCO}_{3}^{-}$was reduced (Figure 3A,B). These findings suggest a limited capability to compensate for $\mathrm{pH}_{\mathrm{e}}$ disturbances caused by high seawater $\mathrm{PCO}_{2}$. According to a crustacean model by Freire et al. [55], proton $\left(\mathrm{H}^{+}\right)$excretion is generated by apical vacuolar-type $\left(\mathrm{H}^{+}\right)$-ATPase $\left(\mathrm{V}\left(\mathrm{H}^{+}\right)\right.$-ATPase) and/or sodium/proton exchanger (NHE), the latter dependent on sodium/potassium-ATPase $\left(\mathrm{Na}^{+} / \mathrm{K}^{+}\right.$-ATPase). $\mathrm{HCO}_{3}{ }^{-}$is enriched in the hemolymph by basolateral anion exchangers. Enzymes that support active ion transport are the intracellular carbonic anhydrase (CA) and, in terms of a general support of energy consuming mechanisms, arginine kinase (AK). CA is assumed to accelerate the dissociation of carbonic acid $\left(\mathrm{H}_{2} \mathrm{CO}_{3}\right)$ and provide the substrate for $\mathrm{H}^{+}$and $\mathrm{HCO}_{3}{ }^{-}$transporters [55]. AK catalyses the reversible dephosphorylation of phosphoarginine, contributing to the restoration of adenosine triphosphate (ATP) used in energy consuming processes [59]. The expression of corresponding genes, $\mathrm{V}\left(\mathrm{H}^{+}\right)$-ATPase, AK and partial sequences of two alpha CAs was significantly up-regulated at intermediate $\mathrm{CO}_{2}$, whereas such mRNA concentrations were only moderately increased at high $\mathrm{CO}_{2}$ (II) (Table 2). These expression levels follow the course of the hemolymph $\mathrm{HCO}_{3}^{-}$parameters and the more effective acid-base regulation of adult $H$. araneus under moderately elevated $\mathrm{CO}_{2}$. However, only a few sequences encoding for $\mathrm{Na}^{+} / \mathrm{K}^{+}$-ATPase were up-regulated under $\mathrm{CO}_{2}$, in contrast to their response to elevated temperature treatment (III). Under the combined effect of temperature and $\mathrm{CO}_{2}$ $\mathrm{Na}^{+} / \mathrm{K}^{+}$-ATPase was also up-regulated. Another enzyme, DOPA decarboxylase, which catalyses the biosynthesis of dopamine by decarboxylation of L-DOPA, was found down-regulated at moderate (intermediate) $\mathrm{CO}_{2}$ elevations (I). Elevated dopamine leads to increased sodium influx and concomitantly, increased $\mathrm{Na}^{+} / \mathrm{K}^{+}$-ATPase activity in gills of $C$. maenas [60]. In light of this finding constant mRNA levels of $\mathrm{Na}^{+} / \mathrm{K}^{+}$-ATPase at intermediate $\mathrm{CO}_{2}$ (I) indicate that the down-regulation of DOPA decarboxylase may even prevent an activation of $\mathrm{Na}^{+} / \mathrm{K}^{+}$-ATPase (Table 2). The gene expression of other transporters, supposed to be involved in acid-base regulation, such as NHE and/ or bicarbonate/chloride co-transporter were not influenced at all by elevated $\mathrm{PCO}_{2}$ values or temperature. Acid-base regulation predominantly via the $\mathrm{V}\left(\mathrm{H}^{+}\right)$-ATPase (as seen in the present transcriptome) might involve minimal disturbance to ionic composition, e.g. cellular sodium homeostasis which would be affected by strong involvement of $\mathrm{Na}^{+} / \mathrm{K}^{+}$-ATPase. In the sipunculid $S$. nudus, extracellular acidosis induced a shift in ion transporters during hypercapnia from high to low energy cost mechanisms of acid-base regulation, resulting in decreased $\mathrm{Na}^{+/} \mathrm{K}^{+}$-ATPase activity due to lower requirement for sodium regulation [25,27]. In line with our present observations these results suggest a $\mathrm{pH}$ regulation system 

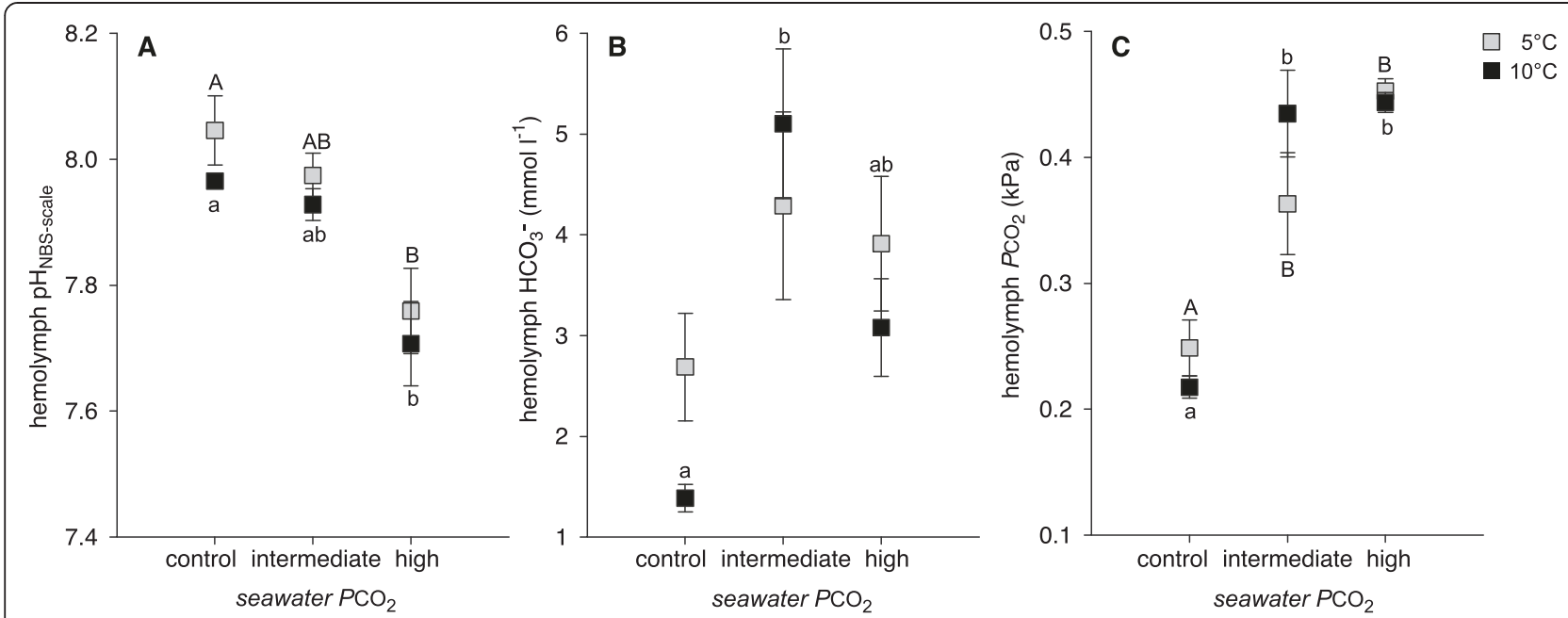

Figure 3 Hemolymph acid-base status Hyas araneus (A, pH-values; $\mathrm{B}$, bicarbonate levels; $\mathrm{C}, \mathrm{PCO}_{2}$ levels) in response to different exposure experiments. Squares represent the means with error bars depicting the standard error for each treatment. Grey squares refer to

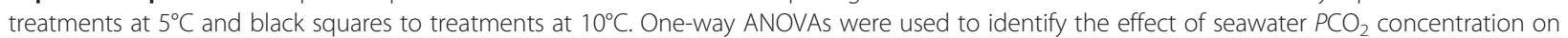
hemolymph $\mathrm{pH}$, bicarbonate $\left(\mathrm{HCO}_{3}^{-}\right)$and $\mathrm{PCO}_{2}$. A Holm-Sidak test for multiple comparisons was used for posteriori analysis $(p<0.05)$. Differing letters indicate significant differences; identical letters indicate no significant difference. Capital letters denote differences for $5^{\circ} \mathrm{C}$ treatments and lower cases for $10^{\circ} \mathrm{C}$ treatments.

independent of $\mathrm{Na}^{+} / \mathrm{K}^{+}$-ATPase being used under hypercapnic exposure (Figure 4). No significant up-regulation of apical bicarbonate anion exchangers was observed. In C. sapidus, $\mathrm{CO}_{2}$ induced acid-base disturbances $\left(\mathrm{PCO}_{2}\right.$ $10,000 \mu \mathrm{atm}$ ) were mainly compensated by an uptake of $\mathrm{HCO}_{3}{ }^{-}$from the surrounding seawater via the gill epithelia [39]. However, our results with no up-regulation of respective transporters suggests hemolymph buffering may be achieved through the dissociation of respiratory $\mathrm{CO}_{2}$ resulting in an accumulation of $\mathrm{HCO}_{3}{ }^{-}$in the hemolymph. This might be exceptionally for crustaceans with low compensatory capacities. In $H$. araneus, also no significant up-regulation of basolateral bicarbonate anion exchangers was observed. However, expression of the anion channel bestrophin was significantly enhanced (Table 2, Figure 4). Bestrophin is activated by calcium $\left(\mathrm{Ca}^{2+}\right)$ and enhances membrane permeability for anions, such as chloride and $\mathrm{HCO}_{3}{ }^{-}$[61]. Even though bestrophin is commonly found in the retinal pigment epithelium, ion channels of this family have been identified in different tissues and are involved in a variety of cellular processes [62]. Its role in responses to elevated $\mathrm{CO}_{2}$ remains to be investigated.

\section{Energy metabolism}

Acid-base regulation compensating for $\mathrm{CO}_{2}$ induced disturbances likely entails a metabolic cost due to the ATP demanding movement of $\mathrm{H}^{+}$by ion transporters [25]. Elevated metabolic rates have already been observed under hypercapnia exposure $[26,63]$, however, the mechanisms causing such cost increments remain unidentified.
The differential expression analysis revealed an upregulation of complex I and complex IV of the electron transport system (ETS) during exposure to intermediate $\mathrm{CO}_{2}$ levels (i,iv) (Table 2). Transcripts encoding for NADH dehydrogenase and cytochrome c oxidase subunits were significantly up-regulated above control levels possibly leading to an increase in mitochondrial density to meet the increased energy demand. Interestingly, complex II and III were not affected by hypercapnia exposure. Increased activities of complex I and IV activated by protein kinase A (PKA) resulted in an increased oxidative phosphorylation and ATP synthesis in human kidney cells [64]. The activation was triggered by a soluble adenylyl cyclase (sAC) induced signalling pathway that implies phosphorylation of PKA being stimulated by cyclic adenosine monophosphate (cAMP), which, in turn, is formed from sAC. In mammals and in elasmobranchs it is known that sAC is stimulated by $\mathrm{HCO}_{3}{ }^{-}[65,66]$, which would thereby support an increased activity of mitochondrial electron transport system under hypercapnia exposure. cAMP and PKA regulate key enzymes, such as complex IV, by alterating gene expression $[66,67]$. Considering the higher extracellular bicarbonate levels in animals under hypercapnia (Figure 4) this signalling pathway possibly led to the increased up-regulation in ETS related genes and/or increased activity and thus might explain how the organisms meet the suggested increase in ATP demand (Figure 4).

An increased ATP production by the ETS would also lead to an elevated demand for metabolic substrates and turnover of the resulting reduction equivalents $\mathrm{NADH}$, 
Table 2 Regulation of transcripts of specific interest in the hypercapnia and elevated temperature experiments on Hyas araneus

\begin{tabular}{|c|c|c|c|c|c|c|c|}
\hline Accession no. & Description & Rank & Treatment (I) & Treatment (II) & Treatment (III) & Treatment (IV) & Treatment (V) \\
\hline HAAI01016321 & uricase & 10 & -5.24 & -4.27 & -3.68 & -7.10 & -6.20 \\
\hline HAAI01006676 & trehalose-6-phosphate synthase $1 \mathrm{a}$ & 21 & -4.45 & -2.42 & -2.13 & -6.05 & -4.57 \\
\hline HAAI01003297 & cuticle proprotein & 24 & 5.88 & 1.22 & 2.81 & 3.98 & 1.87 \\
\hline HAAI01001762 & actin & 53 & -1.65 & 0.48 & 5.06 & -0.34 & -1.03 \\
\hline HAAI01004150 & trehalose 6-phosphate synthase 1 & 61 & -4.35 & -1.68 & -2.73 & -4.88 & -3.99 \\
\hline HAAI01015640 & vitellogenin like & 66 & 4.82 & 3.35 & 0.68 & 3.28 & -0.13 \\
\hline HAAI01018061 & peroxiredoxin & 79 & 4.67 & 4.31 & 1.81 & 3.92 & 4.09 \\
\hline HAAI01010911 & enoyl COA hydratase & 80 & -1.11 & -0.65 & 0.34 & -0.47 & -4.67 \\
\hline HAAI01016834 & like adducin related protein & 83 & 4.62 & 3.22 & 0.81 & 3.30 & 0.29 \\
\hline HAAI01016838 & GSH peroxidase like & 87 & 3.67 & 4.61 & 2.81 & 3.92 & 4.19 \\
\hline HAAI01015788 & vitellogenin like & 100 & 4.48 & 3.61 & 1.22 & 3.60 & -0.71 \\
\hline HAAI01000380 & glucose-6-phosphat dehydrogenase & 105 & -3.16 & -4.45 & -2.56 & -3.41 & -2.87 \\
\hline HAAI01017747 & sodium glucose cotransporter & 113 & 2.94 & 4.36 & 0.64 & 1.98 & 1.29 \\
\hline HAAI01002706 & trehalose 6-phosphate synthase $1 \mathrm{~b}$ & 117 & -3.87 & -1.10 & -2.20 & -4.32 & -3.11 \\
\hline HAAI01012389 & isocitrate dehydrogenase I & 128 & -1.18 & -2.36 & -0.55 & -4.19 & -2.88 \\
\hline HAAI01000602 & dopa decarboxylase & 138 & -3.37 & -2.78 & -2.26 & -2.80 & -4.09 \\
\hline HAAI01003033 & troponin I & 175 & -0.33 & 1.22 & 3.78 & -0.02 & 0.29 \\
\hline HAAI01015542 & heat shock protein 90 & 192 & -3.07 & 1.07 & -3.68 & -0.09 & -3.30 \\
\hline HAAI01002164 & alpha carbonic anhydrase & 197 & 3.67 & 1.80 & 1.64 & 3.45 & 1.87 \\
\hline HAAI01019079 & ascorbate peroxidase & 198 & 3.67 & 2.11 & 1.17 & 2.23 & -2.52 \\
\hline HAAI01009105 & heat shock protein 90 & 203 & 3.61 & 2.42 & 0.36 & 1.98 & -2.03 \\
\hline HAAI01019113 & vitellogenin like & 226 & 3.52 & 2.39 & -0.36 & 2.48 & -1.56 \\
\hline HAAI01018669 & vitellogenin like & 234 & 3.50 & 2.29 & 0.15 & 2.00 & -2.03 \\
\hline HAAI01016527 & cytochrome p450 like & 236 & 3.23 & 2.03 & 0.07 & 3.47 & 2.61 \\
\hline HAAI01009026 & cuticle protein like & 291 & -0.47 & 3.20 & 0.01 & 0.98 & -0.36 \\
\hline HAAI01010727 & gelsolin precursor & 303 & 1.67 & 0.68 & 3.13 & 0.64 & 1.29 \\
\hline HAAI01018844 & alpha tubulin & 309 & 3.11 & 1.41 & 1.46 & 2.74 & -0.20 \\
\hline HAAI01008700 & arginine kinase & 338 & 3.01 & 2.27 & 1.43 & 2.76 & 2.14 \\
\hline HAAI01019135 & carbohydrate phosphorylase like & 344 & 2.67 & 1.48 & 1.26 & 2.99 & 1.21 \\
\hline HAAI01004058 & cuticle protein & 359 & 2.93 & 0.22 & -0.55 & 0.20 & -0.71 \\
\hline HAAI01015598 & heat shock protein 90 & 367 & 2.90 & 1.47 & -0.19 & 1.85 & -0.71 \\
\hline HAAI01019120 & bestrophin like & 368 & 2.89 & 1.8 & 2.13 & 1.56 & 1.16 \\
\hline HAAI01000761 & heat shock protein 70 & 381 & 2.84 & 1.94 & 1.30 & 2.61 & 1.37 \\
\hline HAAI01005842 & cuticle protein like & 386 & 2.81 & 0.48 & 1.54 & 0.63 & -0.45 \\
\hline HAAI01001265 & beta tubulin & 403 & 2.77 & 1.77 & 0.97 & 1.98 & 1.02 \\
\hline HAAI01018645 & V1-ATPase subunit & 427 & 2.69 & 1.80 & 1.27 & 2.54 & 1.46 \\
\hline HAAI01018783 & cuticle protein & 435 & 2.67 & 0.71 & 1.49 & 1.50 & 1.61 \\
\hline HAAI01004930 & heat shock protein 90 & 447 & 2.63 & 1.86 & 1.24 & 2.58 & 0.92 \\
\hline HAAI01007246 & vitellogenin like & 455 & 2.61 & 2.15 & -1.10 & 0.98 & -1.45 \\
\hline HAAI01003327 & actin & 461 & 2.53 & 2.26 & 1.06 & 2.60 & 1.72 \\
\hline HAAI01000796 & alpha tubulin & 466 & 2.59 & 2.06 & 1.09 & 2.34 & 1.70 \\
\hline HAAI01018213 & alpha-glucosidase & 477 & 1.83 & 1.26 & 1.56 & 2.55 & 2.39 \\
\hline HAAI01005237 & alpha carbonic anhydrase like & 478 & 2.55 & 1.80 & 0.52 & 2.42 & 0.91 \\
\hline
\end{tabular}


Table 2 Regulation of transcripts of specific interest in the hypercapnia and elevated temperature experiments on Hyas araneus (Continued)

\begin{tabular}{|c|c|c|c|c|c|c|c|}
\hline HAAI01001455 & cuticle protein like & 498 & -1.26 & -1.86 & -0.58 & -2.44 & -2.51 \\
\hline HAAI01014269 & cuticle protein like & 514 & -0.50 & -1.08 & -0.57 & -1.66 & -2.48 \\
\hline HAAI01008420 & troponin I & 519 & 0.02 & -0.73 & -2.46 & -0.88 & -1.81 \\
\hline HAAI01002591 & superoxide dismutase & 535 & -0.10 & -1.65 & -0.62 & -1.49 & -2.42 \\
\hline HAAI01019124 & na $+k+-$ atpase alpha subunit & 536 & 0.81 & 0.22 & 1.82 & 2.09 & 2.41 \\
\hline HAAI01007529 & $\begin{array}{l}\text { glyceraldehyde 3-phosphate } \\
\text { dehydrogenase }\end{array}$ & 546 & 2.39 & 1.60 & 0.69 & 2.36 & 1.07 \\
\hline HAAI01004651 & actin & 556 & 2.38 & 1.44 & 0.52 & 1.82 & 1.33 \\
\hline HAAI01005807 & cytochrome c oxidase subunit ii & 559 & 2.23 & 1.82 & 0.96 & 2.37 & 1.33 \\
\hline HAAI01001460 & cuticle protein like & 560 & -0.72 & -1.31 & -0.72 & -1.62 & -2.37 \\
\hline HAAI01001217 & cuticle protein & 562 & 2.37 & 1.10 & 2.21 & 0.40 & -0.98 \\
\hline HAAI01003904 & ankyrin related protein like & 576 & 1.33 & 1.27 & 2.33 & 0.82 & 0.59 \\
\hline HAAI01000424 & cytochrome c oxidase subunit i & 583 & 2.32 & 1.56 & 1.10 & 2.28 & 0.84 \\
\hline HAAI01001438 & nadh dehydrogenase subunit & 598 & 1.95 & 1.46 & 0.87 & 2.27 & 1.29 \\
\hline HAAI01006730 & heat shock protein 90 & 608 & 2.24 & 1.44 & 0.96 & 2.13 & 1.29 \\
\hline HAAI01005819 & cuticle protein like & 614 & 1.55 & 1.87 & 0.79 & 2.14 & 2.23 \\
\hline HAAI01015787 & alpha tubulin & 630 & 2.20 & 0.85 & 0.47 & 1.88 & -0.27 \\
\hline HAAI01002070 & vitellogenin like & 634 & 2.20 & 1.77 & -1.05 & 1.32 & -1.57 \\
\hline HAAI01014788 & thioredoxin & 647 & -1.73 & -2.18 & -0.50 & -1.38 & -1.52 \\
\hline HAAI01006091 & gelsolin precursor & 670 & 0.84 & 0.73 & 2.10 & 0.37 & -0.28 \\
\hline HAAI01000874 & alpha tubulin & 673 & 2.03 & 2.09 & 0.90 & 1.31 & 1.69 \\
\hline HAAI01000485 & cytochrome c oxidase subunit iii & 711 & 1.94 & 1.28 & 0.60 & 2.02 & 0.90 \\
\hline HAAI01008219 & gelsolin precursor & 738 & 0.89 & 0.76 & 1.97 & 0.25 & -0.35 \\
\hline HAAI01014184 & thioredoxin & 751 & -1.08 & -0.93 & -1.23 & -1.94 & -1.80 \\
\hline HAAI01002593 & thioredoxin peroxidase & 769 & -1.89 & -0.72 & -0.98 & -1.52 & -1.52 \\
\hline HAAI01005614 & cuticle protein like & 804 & 1.44 & 0.78 & 1.79 & 1.18 & -0.21 \\
\hline HAAI01006347 & cuticle protein like & 817 & 1.28 & -0.22 & 1.75 & 1.37 & 1.42 \\
\hline HAAI01018927 & spectrin like & 822 & 1.58 & 0.51 & 1.74 & 1.09 & 0.50 \\
\hline HAAI01000352 & nesprin like & 827 & 1.70 & 0.72 & 1.73 & 1.42 & 1.58 \\
\hline
\end{tabular}

Transcripts significantly regulated in response to hypercapnia and elevated temperature as identified by DESeq analysis (for details, see Methods). Accession number (accession no.) refers to the transcriptome of Hyas araneus [40] and the database ENA (EMBL). Details on transcript description and transcript length are listed for each transcript. Transcripts are sorted according to the rank in absolute regulation regardless of the treatment. Changes are given in log ${ }_{2}$-fold change for each treatment separately. Bold numbers represent significantly up-regulated transcripts; bold and italic numbers represent significantly down-regulated transcripts.

$\mathrm{FADH}_{2}$ ). In the intermediate $\mathrm{CO}_{2}$ treatments (I, IV), the glycolytic pathway only experienced a significant upregulation of glyceraldehyde-3-phosphate dehydrogenase (GAPDH) (Table 2), whereas the rate-limiting enzymes phosphofructokinase or pyruvate kinase remained unaffected, suggesting no general up-regulation of glycolysis. However, the enhanced expression of sodium glucose transporter indicates increased capacity for glucose transport from the hemolymph into the gill cells (Table 2). Trehalose is the major hemolymph sugar in insects and decapod crustaceans, with higher levels than glucose [68,69]. Enzymes for trehalose synthesis were found in crustacean tissues, including gills [70]. Trehalose and its fast transport into cells and consecutive transformation into glucose reflect its immediate availability to meet sudden bouts of energy demand. Accordingly, a 6.7 fold increase of trehalose concentration was measured in the hemolymph of $C$. maenas over 10 days under osmotic stress [71]. In $H$. araneus, however, the expression of trehalose-6-phosphate synthase was significantly down-regulated in all treatments (I-V) suggesting suppressed synthesis of the already depleted trehalose stores (Table 2). Significant up-regulation of transcripts encoding for glycogen phosphorylase (I, IV) and alpha glucosidase (IV) was found instead. Both enzymes catalyse the glucose releasing steps of glycogenolysis indicating the use of glycogen as a glucose source during long-term increased demand. 


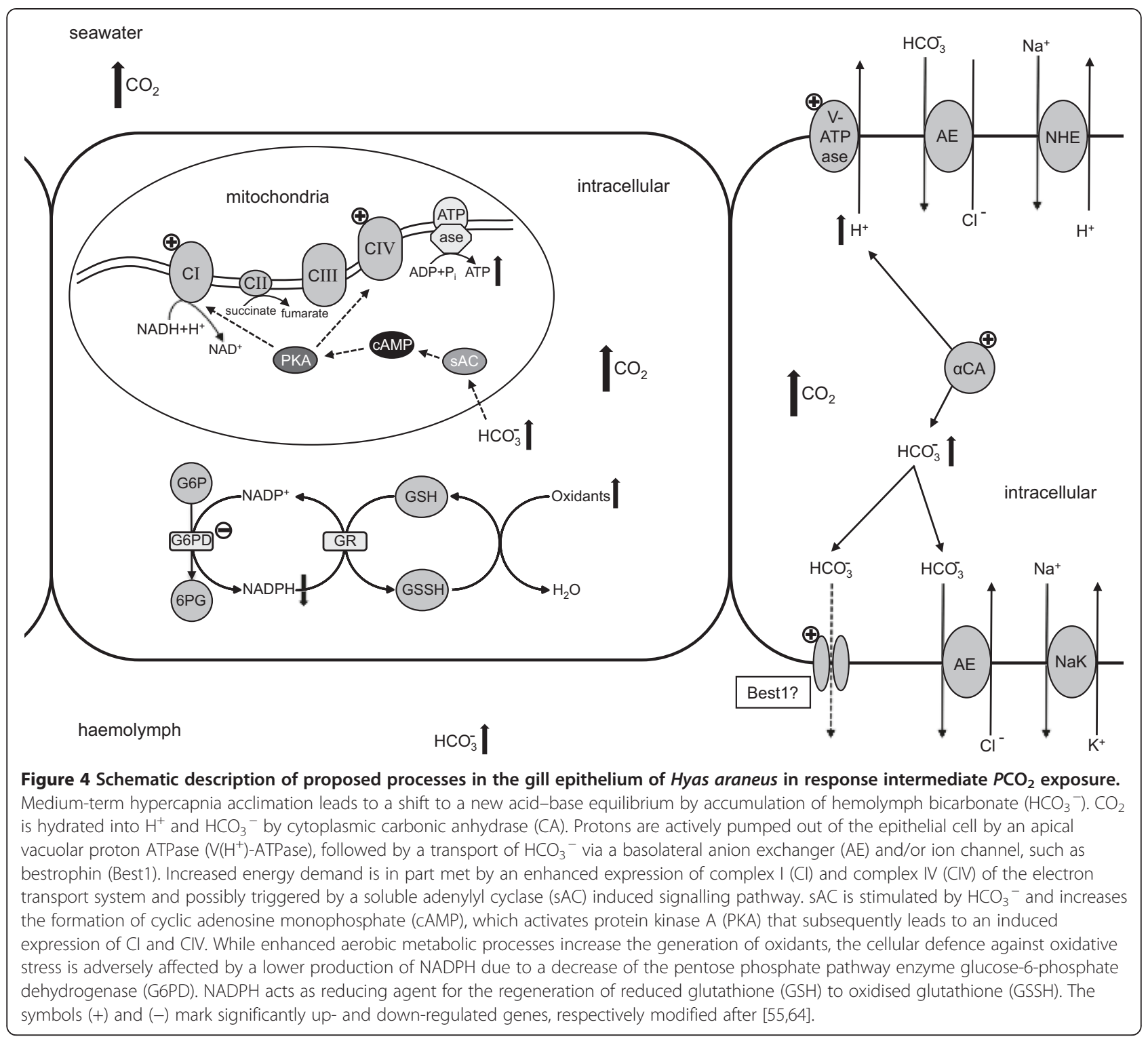

Enhanced demand for glucose is paralleled by a downregulation of glucose-6-phosphate dehydrogenase (G6PD) in all treatments (I-V) indicating the potentially reduced production of NADPH (Table 2). G6PD is the key enzyme of the oxidative phase of the pentose phosphate pathway, the main source of NADPH for biosynthetic pathways in the cells (Figure 4). Furthermore, the cytosolic (NADP dependent) isocitrate dehydrogenase (IDH) was significantly down-regulated under intermediate $\mathrm{CO}_{2}$ levels at high temperature (IV), also suggesting lowered biosynthetic rates such as lipid biosynthesis under combined exposure (Table 2).

\section{Oxidative stress}

Besides being involved in lipid biosynthesis, NADPH is an important reducing agent in cellular antioxidative defence, e.g. by regenerating reduced glutathione, a major cellular antioxidant (Figure 4). Thus, besides a general down-regulation of anabolic reactions it seems conceivable that $H$. araneus encounters a reduced capacity to counteract oxidative stress under hypercapnic and thermal stress.

Significant changes in the expression of several genes involved in cellular antioxidant defence, including several peroxidases, indicate potential oxidative stress in $H$. araneus under intermediate $\mathrm{CO}_{2}$ exposure (I). These changes in expression level were less pronounced under high $\mathrm{CO}_{2}$ (II), suggesting a decreasing acclimation capacity of the $H$. araneus with increasing external $\mathrm{PCO}_{2}$ (Table 2, see above). Among up-regulated genes, especially genes associated with the detoxification of hydrogen peroxide $\left(\mathrm{H}_{2} \mathrm{O}_{2}\right)$ were affected under hypercapnia exposure. 
An ascorbate peroxidase (APX) was significantly upregulated under intermediate $\mathrm{CO}_{2}$ concentrations (I). APX is a peroxidase that utilizes ascorbate as electron donor to detoxify $\mathrm{H}_{2} \mathrm{O}_{2}$ into water (Table 2). Additionally, a glutathione peroxidase (GPX) that reduces $\mathrm{H}_{2} \mathrm{O}_{2}$, using glutathione as substrate, was up-regulated under high $\mathrm{CO}_{2}$ exposure (II). This contrasts the down-regulation of two thiol-specific peroxiredoxin-1, at intermediate $\mathrm{CO}_{2}$ concentration (I), indicating a balanced response possibly by differential transcription of different splice variants. Peroxiredoxins are ubiquitous enzymes detoxifying peroxides, such as $\mathrm{H}_{2} \mathrm{O}_{2}$, by oxidising their active cysteine site using peroxide as substrate and are regenerated by oxidation of a thiol-containing electron donor, commonly thioredoxin [72]. However, only two sequences encoding for a thiol-containing protein (thioredoxin-1) were significantly down-regulated (II, IV).

The up-regulation of genes for anti-oxidants, such as glutathione peroxidase and peroxiredoxin, may indicate compensation for enhanced ROS (reactive oxygen species) production and concomitantly oxidative stress in the gill tissue of $H$. araneus under $\mathrm{CO}_{2}$ exposure. This is further supported by a significant up-regulation of a ribosomal cytochrome p450 like gene in the intermediate $\mathrm{CO}_{2}$ treatment (I). Cytochrome p450 is involved in the oxidative metabolism of a variety of organic substrates and incomplete catalytic processes can result in a continuous release of ROS [73,74]. In contrast, a transcript encoding for urate oxidase (uricase) was significantly down-regulated in all treatments (I-V) (Table 2). Uricase is commonly located in the peroxisomes of the hepatopancreas tissue, however, uricase activity has also been detected in gill tissue of the kuruma shrimp Marsupenaeus japonicas [75]. Uricase catalyses the reaction from urate to allantoin and contributes to the generation of $\mathrm{H}_{2} \mathrm{O}_{2}$ by the oxidation of uric acid [76]. Consequently, a down-regulation of uricase may contribute to alleviate the generation of ROS. Interestingly, $\mathrm{CO}_{2}$ exposure also led to an increase in several vitellogenin like transcripts (Table 2). Although expression of vitellogenins is generally sex- and tissue-specific, the expression in both sexes of the mud shrimp Upogebia major [77], revealed a positive effect on oxidative stress resistance regardless of the developmental stage. Vitellogenin is also beneficial for oxidative stress resistance in honeybees, Apis mellifera [78]. Even if the function of vitellogenin in oxidative stress resistance is far from being completely understood and further investigations are needed to validate this hypothesis, the strong up-regulation of vitellogenin under $\mathrm{CO}_{2}$ (I, II, IV) may indicate that vitellogenin is an important protein in the resistance to $\mathrm{CO}_{2}$-induced oxidative stress (see below).

Hypercapnia induced enhancement of oxidative stress defence was recently demonstrated in the Eastern oyster, Crassostrea virginica [79]. In a proteomic approach, an up-regulation of several proteins, e.g. superoxide dismutase and several peroxiredoxins, was detected after exposure to high $\mathrm{PCO}_{2}(\sim 3,520 \mu \mathrm{atm})$ for 2 weeks. The authors suggested several ways of how increased $\mathrm{CO}_{2}$ levels could directly or indirectly cause oxidative stress. On the one hand, a reaction of $\mathrm{CO}_{2}$ with peroxynitrite, a $\mathrm{ROS}$ formed through the reaction between superoxide anions and nitric oxide, resulting in the formation of reactive carbonate and nitrogen species, can lead to oxidative stress by oxidizing molecular compounds [80]. On the other hand, an indirect influence of elevated $\mathrm{CO}_{2}$ and/or $\mathrm{pH}$ could adversely affect mitochondrial functions and/or the non-enzymatic production of ROS [79]. However, our findings cannot support a direct influence of $\mathrm{CO}_{2}$ on oxidative stress generation, as one would assume an increase in the response to oxidative stress with increasing seawater $\mathrm{CO}_{2}$. Our data rather indicate an indirect influence of elevated $\mathrm{CO}_{2}$ on ROS production, likely by enhanced ROS production due to metabolic stimulation. The suggested increase in oxidative metabolic processes might cause enhanced ROS production and would also explain why the oxidative stress response was higher under intermediate $\mathrm{CO}_{2}$ than in the high $\mathrm{CO}_{2}$ treatment.

\section{Cell structure}

It is well known that the formation of ROS can damage lipids, proteins and DNA e.g. [81]. A large group of genes that belong to the functional category 'cytoskeleton' include several actins and tubulins which are up-regulated together with the antioxidant genes under $\mathrm{CO}_{2}$ exposure. The cytoskeleton is one major target for oxidative stress (Table 2) when the exposed cysteine component of actin forms oxidized derivates, such as intermolecular disulfide bridges [82]. This presumably has adverse effects on the interaction between actin and actin binding proteins and leads to changes in the structure of the actin cytoskeleton. The up-regulation of two transcripts encoding for actin in both intermediate $\mathrm{CO}_{2}$ treatments (I, IV) and the high $\mathrm{CO}_{2}$ treatment (II) may counter the damages caused by oxidative stress. An additional up-regulation of two actin binding proteins, nesprin and adducin, further supports the need for structural adaptation under oxidative stress triggered by $\mathrm{CO}_{2}$ exposure (Table 2). There is strong evidence that ROS induce the expression of tubulin [83], which could explain the up-regulation of $\beta$-tubulin and three transcript sequences encoding for $\alpha$-tubulin in both intermediate $\mathrm{CO}_{2}$ treatments (I, IV) and the high $\mathrm{CO}_{2}$ (II) treatment (Table 2). Although the effect of oxidative stress on the cytoskeleton is still poorly understood and needs further investigation, an interaction of oxidative stress and adaptive changes in the cytoskeleton is well recognized $[79,82]$ and supported by our findings.

Besides enhanced antioxidative defence, a reorganisation of the cytoskeleton may occur in gill epithelia during the 
initial stage of hypercapnia acclimation. In C. maenas, a reorganisation of gill epithelia was observed after shortterm exposure to very high $\mathrm{PCO}_{2}$ ( 4,340 $\mu$ atm; 7 days), but not after medium-term exposure to high $\mathrm{PCO}_{2}$ ( 2,270 $\mu$ atm; 11 weeks) [36]. Similarly, a reorganization of the cytoskeleton may not occur during medium-term $\mathrm{CO}_{2}$ acclimation of $H$. araneus (10 weeks). The response of genes that belong to the functional category 'cytoskeleton' was higher at intermediate $\mathrm{CO}_{2}$ (I, IV) than at high $\mathrm{CO}_{2}$ (II), in line with the findings in antioxidative defence. This also suggests that the changes observed result from oxidative stress via enhanced metabolic rate at intermediate $\mathrm{CO}_{2}$ with the cytoskeleton as a direct target of ROS formation.

Cytoskeletal genes also responded to elevated temperature (III). Several genes encoding for actin-binding proteins as well as membrane and cuticle proteins were significantly up-regulated (Table 2). Three transcripts of gelsolin, an actin-binding protein and regulator of actin filament assembly, were significantly up-regulated. The expression of an actin-binding nesprin, a membranebinding ankyrin and an actin-related cytoskeletal structure protein spectrin was also increased. Warming affects various cellular processes, including stability and/or dynamics of the cytoskeleton for review see [84]. An increase in cytoskeletal gene expression despite the general downregulation of expression levels indicates a requirement for the stabilization of the cytoskeleton, possibly elicited by the warm-induced stimulation of metabolic rate and associated ROS formation. Interestingly, such up-regulation of cytoskeletal gene expression could not be seen in under combined intermediate $\mathrm{PCO}_{2}$ and high temperature (IV, $\mathrm{V})$, suggesting that the general down-regulation induced by high $\mathrm{CO}_{2}$ also affects cytoskeleton assembly.

Commonly, stresses such as temperature extremes, cellular energy depletion, and extreme concentrations of ions, osmolytes and gases induce the synthesis of heat-shock proteins (HSP) for review see [85]. However, HSP expression levels being unchanged in the high temperature treatment (III) suggest that $10^{\circ} \mathrm{C}$ is not a temperature extreme for the Arctic $H$. araneus population. In contrast, the expression of several HSPs was upregulated under $\mathrm{CO}_{2}$ exposure (Table 2). One HSP70 was up-regulated in both the intermediate and the high $\mathrm{CO}_{2}$ treatments (I, II, IV). Four transcripts encoding for HSP90 were significantly up-regulated in the intermediate $\mathrm{CO}_{2}$ treatment (I) and two in the intermediate $\mathrm{CO}_{2}$ plus high temperature treatment (IV). In treatments I, III, and V one HSP90 showed decreased expression. Acting as molecular chaperones, HSPs can play an important role in maintaining proteins in a folded or unfolded state, controlling the unintended aggregation of proteins or target proteins for degradation [86]. Their induced expression, especially under intermediate $\mathrm{CO}_{2}$ concentrations, paired with increases in mRNA transcripts for proteins involved in antioxidant defence suggest an increased capacity to defend the cell against cellular damage. The up-regulation specifically of HSP90 suggests HSP90 to be of particular importance in maintaining protein homeostasis.

\section{Conclusions}

Based on a comprehensive expression analysis of genes related to acid-base regulation, metabolism, cell structure and their coupling to the stress response, this study has identified moderate, but distinct responses to ocean acidification in gills of adult $H$. araneus. We could demonstrate that the molecular response strongly depends on the $\mathrm{CO}_{2}$ concentration. At $\mathrm{PCO}_{2}$ values proposed for the end of the century, changes in expression suggest elevated metabolism caused by stimulated acid-base regulation and associated with increased oxidative stress. This up-regulation was attenuated at even higher $\mathrm{PCO}_{2}$ (business as usual scenario for Year 2300) with expression levels closer to control values (Figure 5), indicating down-regulation of these processes. Responses in transcripts related to acid-base regulation and energy metabolism were in line with those observed at elevated temperature. Observations under hypercapnia in the blue mussel $M$. edulis are in line with these conclusions. An increase in aerobic metabolism under intermediate $\mathrm{PCO}_{2}$ exposure $(<2,400 \mu \mathrm{atm})$ was followed by a decrease at higher $P \mathrm{PO}_{2}[87,88]$. In earlier studies on marine invertebrates, high $\mathrm{PCO}_{2}$ exposure ( 3,200-5,000 $\mu$ atm) induced a decrease in metabolic rates. In the mussel Mytilus galloprovincialis and the decapod crab Necora puber, a decrease in respiration rates was seen in response to long-term exposure at a $\mathrm{PCO}_{2}$ of approx. 5,000 and $3,200 \mu \mathrm{atm}$, respectively [6,9]. Our findings suggest a $P \mathrm{CO}_{2}$ dependent threshold where metabolic stimulation might turn into metabolic depression. In $H$. araneus this threshold may be reached at a $P C \mathrm{O}_{2}$ of approximately 2,000 $\mu \mathrm{atm}$. Although further examinations besides transcriptomics covering a broader range of $\mathrm{PCO}_{2}$ concentrations are certainly needed to confirm a possible threshold, a recent meta-analysis revealed that $50 \%$ of all marine crustacean species were negatively affected at this $\mathrm{PCO}_{2}$ [5].

Changes in the expression of genes related to energy metabolism paralleled the expression of those related to acid-base regulation and both paralleled the changes in extracellular $\mathrm{pH}\left(\mathrm{pH}_{\mathrm{e}}\right)$, indicating a feedback regulation between $\mathrm{pH}$ and metabolic rate (Figure 5). In the marine worm S. nudus and the mussel M. galloprovincialis, metabolic depression under $\mathrm{CO}_{2}$ was caused by a drop in $\mathrm{pH}_{\mathrm{e}}[6,27,89]$. $H$. araneus was able to partially compensate for the acidosis via bicarbonate $\left(\mathrm{HCO}_{3}{ }^{-}\right)$accumulation, but capacities were not sufficient to fully 


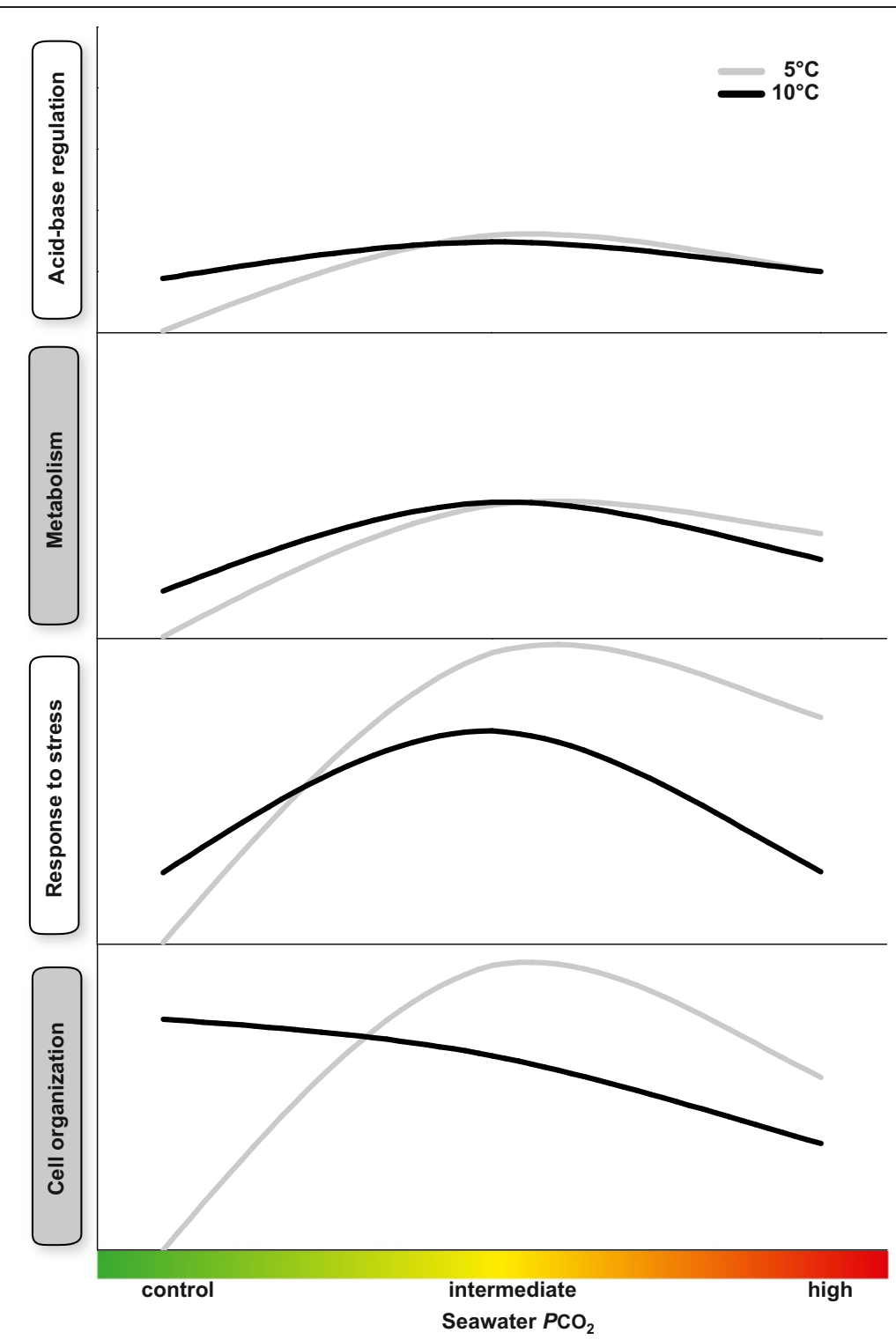

Figure 5 Schematic description of the response of Hyas araneus to different exposure experiments for specific categories. For each treatment, $\log _{2}$-fold changes of all up-regulated transcripts within one specific category were summed and plotted as a line ( $\mathrm{gray}$ line $=5^{\circ} \mathrm{C} ;$ black line $=10^{\circ} \mathrm{C}$ ). Scales are harmonized for all categories. The figure shows how acclimation to warming reduces the transcriptomic response of 'cell organization' and 'response to stress' to elevated $\mathrm{CO}_{2}$ tensions.

compensate. At both experimental temperatures $\left(5^{\circ} \mathrm{C}\right.$ and $10^{\circ} \mathrm{C}$ ) hemolymph acidosis was compensated to the same extent. At high $\mathrm{CO}_{2}$ concentrations, the capacity to fully compensate may be even more limited related to decreased ion transporter expression and activities. Since acid-base regulation is an ATP-consuming process, the decreased expression of metabolism related genes might at least in part be explained by a $\mathrm{pH}_{\mathrm{e}}$-triggered inhibition.

These shifts cause changes in energy balance which can therefore reflect the limits in stress tolerance [90]. A bioenergetic framework [90] builds on the physiological concepts of oxygen- and capacity-limited thermal tolerance
(OCLTT) [91-93] and the dynamic energy budget (DEB) [94]. Two cases distinguished between physiological responses to moderate and extreme environmental stress. Moderate stress induces additional ATP turnover along with a higher metabolic rate, in $H$. araneus exemplified in enhanced acid-base regulation and cellular damage repair from oxidative stress at intermediate $P \mathrm{CO}_{2}$. These mechanisms support long-term persistence at the expense of a shift in energy budget (pejus range) [95]. Even if the enhanced energy demand of stress resistance can be met by increased feeding, it may still result in a reallocation of energy from fitness-related functions such as reproduction 
and growth to maintenance and damage repair [90]. More extreme stress exacerbates the disturbances in homeostasis, exemplified in stronger disturbances in acid-base status as seen in $H$. araneus favouring a suppression of metabolic rate [27] which preserve energy resources and lessen the generation of detrimental metabolic byproducts [90]. In $H$. araneus the respective response to high $P \mathrm{CO}_{2}$ was paralleled by a lower expression of transcripts associated with energy metabolism, stress response and cellular organization. Depressed metabolism would result in insufficient energy balance and time-limited tolerance to environmental stress making long-term survival impossible (pessimum range) [90,93].

To our knowledge, we report the first gene expression profiling study analysing the responses to a combination of two drivers in an osmoconforming crustacean. The study confirms the interdependence of physiological processes affected by elevated seawater $P^{2} \mathrm{CO}_{2}$ and temperature. Furthermore, the study demonstrates the importance of considering projected climate scenarios in experimental work, as responses to increasing seawater $\mathrm{CO}_{2}$ concentrations are not necessarily linear, as presented here.

\section{Additional files}

Additional file 1: Table S1. Summary of sequencing and mapping results for Hyas araneus. Details on treatment, filename and location of sequencing raw data, used sequencer, read count, read length and total size in base pairs (bp), used alignment tool, aligned reads and percentage of aligned reads are listed separately.

Additional file 2: Table S2. Details on primers for quantitative real-time polymerase chain reaction (qRT-PCR) to validate RNASeq data of Hyas araneus. Forward and backward primer sequences and descriptions of target genes used in the qRT-PCR. Accession number (accession no.) refer to the transcriptome of Hyas araneus [40] and the database ENA (EMBL) $\mathrm{R}^{2}$ and efficiency was tested in a GRT-PCR dilution series (for details, see Methods).

Additional file 3: Figure S1. Changes of expression levels of transcripts in gills of Hyas araneus responding to medium-term exposure (10 weeks) at intermediate $P \mathrm{CO}_{2}(\approx 1,000 \mu \mathrm{atm})$ and high temperature $\left(10^{\circ} \mathrm{C}\right)$, analysed by DESeq (gray bars) and quantitative real-time polymerase chain reaction (qRT-PCR) (black bars). Bars represent the mean $\log _{2}$-fold change and standard error (error bars) of the respective gene. Transcripts correspond to primers and genes used in the qRT-PCR (see Additional file 5: Table S3).

Additional file 4: Figure S2. Linear regression between expression levels of transcripts in gills of Hyas araneus responding to medium-term exposure (10 weeks) at intermediate $\mathrm{PCO}_{2}(\approx 1,000 \mu \mathrm{atm})$ and high temperature $\left(10^{\circ} \mathrm{C}\right)$, analysed by DESeq and quantitative real-time polymerase chain reaction (qRT-PCR). Black dots represent the mean $\log _{2}$-fold change of transcripts analysed by DESeq plotted against the corresponding mean $\log _{2}$-fold change analysed by qRT-PCR. $r$ was determined by Pearson Correlation using SigmaPlot 12.0 (Systat Software Inc., San Jose, USA).

Additional file 5: Table S3. Transcript levels changing significantly in gills of Hyas araneus responding to hypercapnia and elevated temperature Transcripts regulated significantly in response to hypercapnia and elevated temperature as identified by DESeq analysis (for details, see Methods). ID and accession number (accession no.) refer to the transcriptome of Hyas araneus [40] and the database ENA (EMBL). Details on transcript description and transcript length are listed for each transcript. Transcripts are sorted according to the rank in absolute regulation regardless of the treatment. Changes are given in $\log _{2}$-fold change for each treatment separately. For details on treatments, see Methods). Bold numbers represent significantly up-regulated transcripts and bold and underlined numbers significantly down-regulated transcripts.

Additional file 6: Figure S3. Smearplot of differentially expressed transcripts in gills of Hyas araneus. All transcripts changed in response to hypercapnia and elevated temperature. Log $_{2}$-fold changes are plotted against mean readcount $\left(\log _{10}\right)$. Blue dots represent transcripts with non-significant changes, red dots depict transcripts significantly regulated as identified by DESeq analysis $(p<0.05)$ and green triangles are transcripts changed significantly and identified by annotation Numbers refer to the total number of significantly up-/down-regulated transcripts. A) treatment $\left.(\mathrm{I})=1,120 \mu \mathrm{atm} \mathrm{PCO}_{2} 5^{\circ} \mathrm{C} ; \mathrm{B}\right)$ treatment $\left.(\mathrm{II})=1,960 \mu \mathrm{atm} P \mathrm{PCO}_{2} 5^{\circ} \mathrm{C} ; \mathrm{C}\right)$ treatment $\left.(\mathrm{III})=390 \mu \mathrm{atm} P \mathrm{PO}_{2} 10^{\circ} \mathrm{C} ; \mathrm{D}\right)$ treatment $(\mathrm{IV})=1,120 \mu \mathrm{atm}$ $\mathrm{PCO}_{2} 10^{\circ} \mathrm{C}$; E) treatment $(\mathrm{V})=1,960 \mu \mathrm{atm} P \mathrm{PO}_{2} 10^{\circ} \mathrm{C}$.

Additional file 7: Table S4. Enrichment analysis in the RNASeq study on Hyas araneus. Results of the enrichment analysis (Fisher's Exact Test; FDR < 0.05) as implemented in Blast2GO $[49,50]$ and reduced by web-based clustering tool REVIGO [51]. Tested were subsets of all significantly regulated transcripts as identified by DESeq (separated by up- and down-regulated transcripts). Reference-set was the full set of annotated sequences of the $\mathrm{H}$. araneus transcriptome [40]. Listed is the Gene Ontology term (GO-term), the name of the functional group (description), the category (molecular function, biological process or cellular component), the false discovery rate (FDR) and whether GO-terms are over- or under-represented (a GO-term is considered over-/under-represented if it appears significantly more often/ less often in the test-set than in the reference-set.

\section{Competing interests}

The authors declare that they have no competing interests.

\section{Authors' contributions}

LH and MS conducted lab experiments. LH and SF performed bioinformatics analysis. $\mathrm{LH}, \mathrm{FCM}, \mathrm{DS}, \mathrm{CH}, \mathrm{HOP}$ and ML conceived the study and coordinated research activities. LH wrote the manuscript; all authors revised and approved the final manuscript.

\section{Acknowledgements}

The authors would like to thank Max Schwanitz for animal collection and Laura Stapp for useful discussions. Financial support was provided by Federal Ministry of Education and Research (BMBF), within phase I of the BIOACID research programme (FKZ 03F0608B, subproject 2.2.1).

\section{Author details}

${ }^{1}$ Integrative Ecophysiology, Alfred Wegener Institute, Bremerhaven, Germany. ${ }^{2}$ Scientific Computing, Alfred Wegener Institute, Bremerhaven, Germany.

${ }^{3}$ Functional Ecology, Alfred Wegener Institute, Bremerhaven, Germany.

Received: 13 January 2014 Accepted: 9 September 2014

Published: 12 September 2014

\section{References}

1. Pörtner $\mathrm{HO}$, Langenbuch $\mathrm{M}$, Michaelidis B: Synergistic effects of temperature extremes, hypoxia, and increases in $\mathrm{CO}_{2}$ on marine animals: from Earth history to global change. J Geophys Res 2005, 110(C9):1-15.

2. Fabry VJ, Seibel BA, Feely RA, Orr JC: Impacts of ocean acidification on marine fauna and ecosystem processes. ICES J Mar Sci 2008, 65:414-432.

3. Melzner F, Gutowska MA, Langenbuch M, Dupont S, Lucassen M, Thorndyke $\mathrm{MC}$, Bleich $\mathrm{M}$, Pörtner $\mathrm{H}-\mathrm{O}$ : Physiological basis for high $\mathrm{CO}_{2}$ tolerance in marine ectothermic animals: pre-adaption through lifestyle and ontogeny? Biogeosciences 2009, 6:1-19.

4. Kroeker KJ, Kordas RL, Crim R, Hendriks IE, Ramajo L, Singh GS, Duarte CM, Gattuso JP: Impacts of ocean acidification on marine organisms: quantifying sensitivities and interaction with warming. Glob Chang Biol 2013, 19(6):1884-1896.

5. Wittmann A, Pörtner H-O: Sensitivities of extant animal taxa to ocean acidification. Nat Clim Chang 2013, doi:10.1038/NCLIMATE1982. 
6. Michaelidis B, Ouzounis C, Paleras A, Pörtner H-O: Effects of long-term moderate hypercapnia on acid-base balance and growth rate in marine mussels Mytilus galloprovincialis. Mar Ecol Prog Ser 2005, 293:109-118.

7. Kurihara $\mathrm{H}$ : Effects of $\mathrm{CO}_{2}$-driven ocean acidification on the early developmental stages of invertebrates. Mar Ecol Prog Ser 2008 373:275-284.

8. Wood HL, Spicer JI, Widdicombe S: Ocean acidification may increase calcification rates, but at a cost. Proc Bio/ Sci/ Royal Soc 2008 275(1644):1767-1773.

9. Small D, Calosi P, White D, Spicer Jl, Widdicombe S: Impact of medium-term exposure to $\mathrm{CO}_{2}$ enriched seawater on the physiological functions of the velvet swimming crab Necora puber. Aquat Biol 2010, 10(1):11-21.

10. Gutowska MA, Pörtner $\mathrm{HO}$, Melzner F: Growth and calcification in the cephalopod Sepia officinalis under elevated seawater $\mathrm{pCO}_{2}$. Mar Ecol Prog Ser 2008, 373:303-309.

11. Whiteley NM: Physiological and ecological responses of crustaceans to ocean acidification. Mar Ecol Prog Ser 2011, 430:257-271

12. Pane EF, Barry JP: Extracellular acid-base regulation during short-term hypercapnia is effective in a shallow-water crab, but ineffective in a deep-sea crab. Mar Ecol Prog Ser 2007, 334:1-9.

13. Walther K, Anger K, Pörtner H-O: Effects of ocean acidification and warming on the larval development of the spider crab Hyas araneus from different latitudes (54 vs. $\left.79^{\circ} \mathrm{N}\right)$. Mar Ecol Prog Ser 2010, 417:159-170.

14. Schiffer M, Harms L, Pörtner HO, Lucassen M, Mark FC, Storch D: Tolerance of Hyas araneus zoea I larvae to elevated seawater $P \mathrm{CO}_{2}$ despite elevated metabolic costs. Mar Biol 2012, 160(8):1943-1953.

15. Walther K, Sartoris F-J, Bock C, Pörtner H-O: Impact of anthropogenic ocean acidification on thermal tolerance of the spider crab Hyas araneus. Biogeosciences 2009, 6:2207-2215.

16. Zittier ZMC, Hirse T, Pörtner H-O: The synergistic effects of increasing temperature and $\mathrm{CO}_{2}$ levels on activity capacity and acid-base balance in the spider crab, Hyas araneus. Mar Biol 2013, 160(8):2049-2062.

17. Spicer Jl, Raffo A, Widdicombe S: Influence of $\mathrm{CO}_{2}$-related seawater acidification on extracellular acid-base balance in the velvet swimming crab Necora puber. Mar Biol 2006, 151(3):1117-1125.

18. Dissanayake $A$, Ishimatsu A: Synergistic effects of elevated $\mathrm{CO}_{2}$ and temperature on the metabolic scope and activity in a shallow-water coastal decapod (Metapenaeus joyneri; Crustacea: Penaeidae). ICES J Mar Sci 2011, 68(6):1147-1154.

19. Carter HA, Ceballos-Osuna L, Miller NA, Stillman JH: Impact of ocean acidification on metabolism and energetics during early life stages of the intertidal porcelain crab Petrolisthes cinctipes. J Exp Biol 2013, 216(Pt 8):1412-1422

20. Wickins JF: The effect of hypercapnia sea water on growth and mineralization in Penaid prawns. Aquaculture 1984, 41:37-48.

21. Long WC, Swiney KM, Harris C, Page HN, Foy RJ: Effects of Ocean Acidification on Juvenile Red King Crab (Paralithodes camtschaticus) and Tanner Crab (Chionoecetes bairdi) growth, condition, calcification, and survival. PLoS One 2013, 8(4):e60959.

22. Kurihara $\mathrm{H}$, Shimode $\mathrm{S}$, Shirayama $\mathrm{Y}$ : Effects of raised $\mathrm{CO}_{2}$ concentration on the egg production rate and early development of two marine copepods (Acartia steueri and Acartia erythraea). Mar Pollut Bull 2004 49(9-10):721-727.

23. Findlay HS, Kendall MA, Spicer Jl, Widdicombe S: Future high $\mathrm{CO}_{2}$ in the intertidal may compromise adult barnacle Semibalanus balanoides survival and embryonic development rate. Mar Ecol Prog Ser 2009, 389:193-202.

24. Watanabe $Y$, Yamaguchi A, Ishida H, Harimoto T, Suzuki S, Sekido Y, Ikeda T, Shirayama Y, Mac Takahashi M, Ohsumi T, Ishizaka J: Lethality of increasing $\mathrm{CO}_{2}$ levels on deep-sea copepods in the Western North Pacific. J Oceanogr 2006, 62:185-196.

25. Pörtner $\mathrm{H}-\mathrm{O}$, Bock $\mathrm{C}$, Reipschläger $\mathrm{A}$ : Modulation of the cost of pHi regulation during metabolic depression: a 31P-NMR study in invertebrate (Sipunculus nudus) isolated muscle. J Exp Biol 2000, 203:2417-2428.

26. Stumpp M, Wren J, Melzner F, Thorndyke MC, Dupont ST: $\mathrm{CO}_{2}$ induced seawater acidification impacts sea urchin larval development I: elevated metabolic rates decrease scope for growth and induce developmental delay. Comp Biochem Physiol A Mol Integr Physiol 2011, 160(3):331-340.

27. Reipschläger A, Pörtner H-O: Metabolic depression during environmental stress: the role of extracellular versus intracellular $\mathrm{pH}$ in Sipunculus nudus. J Exp Biol 1996, 199:1801-1807.
28. Langenbuch $\mathrm{M}$, Pörtner $\mathrm{H}-\mathrm{O}$ : Changes in metabolic rate and $\mathrm{N}$ excreation in marine invertebrate Sipunculus nudus under conditions of environmental hypercapnia: identifying effective acid-base variables. J Exp Biol 2002, 205:1153-1160.

29. Todgham AE, Hofmann GE: Transcriptomic response of sea urchin larvae Strongylocentrotus purpuratus to $\mathrm{CO}_{2}$-driven seawater acidification. J Exp Biol 2009, 212(Pt 16):2579-2594

30. Gracey AY: Interpreting physiological responses to environmental change through gene expression profiling. J Exp Bio/ 2007, 210(Pt 9):1584-1592.

31. Stillman JH, Tagmount A: Seasonal and latitudinal acclimatization of cardiac transcriptome responses to thermal stress in porcelain crabs, Petrolisthes cinctipes. Mol Ecol 2009, 18(20):4206-4226.

32. Lockwood BL, Sanders JG, Somero GN: Transcriptomic responses to heat stress in invasive and native blue mussels (genus Mytilus): molecular correlates of invasive success. J Exp Biol 2010, 213(Pt 20):3548-3558.

33. Lockwood BL, Somero G: Transcriptomic responses to salinity stress in invasive and native blue mussels (genus Mytilus). Mol Ecol 2010, 20(3):517-529.

34. Gracey AY, Troll JV, Somero G: Hypoxia-induced gene expression profiling in the euryoxic fish Gillichthys mirabilis. PNAS 2001, 98(4):1993-1998.

35. Sussarellu R, Fabiouxa C, Le Moullacb G, Fleuryc E, Moragaa D: Transcriptomic response of the Pacific oyster Crassostrea gigas to hypoxia. Mar Genomics 2010, 3(3-4):133-143.

36. Fehsenfeld S, Kiko R, Appelhans Y, Towle DW, Zimmer M, Melzner F: Effects of elevated seawater $\mathrm{PCO}(2)$ on gene expression patterns in the gills of the green crab, Carcinus maenas. BMC Genomics 2011, 12:488.

37. Evans TG, Chan F, Menge BA, Hofmann GE: Transcriptomic responses to ocean acidification in larval sea urchins from a naturally variable $\mathrm{pH}$ environment. Mol Ecol 2013, 22(6):1609-1625.

38. Henry RP, Cameron JN: The role of carbonic anhydrase in respiration, ion regulation and acid-base balance in the aquatic crab Callinectes sapidus and the terrestrial crab Gecarcinus lateralis. J Exp Biol 1983, 103:205-223.

39. Henry RP, Wheatly MG: Interaction of respiration, ion regulation, and acid-base balance in the everyday life of aquatic crustaceans. Am Zool 1992, 32:407-416.

40. Harms L, Frickenhaus S, Schiffer M, Mark FC, Storch D, Pörtner H-O, Held C, Lucassen $\mathrm{M}$ : Characterization and analysis of a transcriptome from the boreal spider crab Hyas araneus. Comp Biochem Physiol Part D Genomics Proteomics 2013, 8(4):344-351.

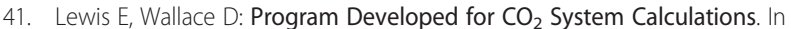
ORNL/CDIAC-105a. Oak Ridge, Tennesse: Carbon Dioxide Information Analysis Center, Oak Ridge National Laboratory, U.S. Department of Energy; 1998.

42. Lenfant C, Aucutt C: Measurement of blood gasses by gas chromatography. Respir Physiol 1966, 1:398-407.

43. Pörtner H-O, Boutillier RG, Tang $Y$, Toews DP: Determination of intracellular $\mathrm{pH}$ and $\mathrm{PCO}_{2}$ after metabolic inhibition by fluoride and nitrilotracetic acid. Respir Physiol 1990, 81:255-274.

44. Pörtner H-O, Bickmeyer U, Bleich M, Bock C, Brownlee C, Melzner F, Michaelidis B, Sartoris F-J, Storch D: Studies of acid-base status and regulation. In Guide of Best Practise for Ocean Acidification Research and Data Reporting. Edited by Riebesell U, Fabry VJ, Hansson L, Gattuso J-P. Luxembourg: Publications Office of the European Union; 2010:137-166.

45. Li H, Durbin R: Fast and accurate short read alignment with Burrows-Wheeler transform. Bioinformatics 2009, 25(14):1754-1760.

46. Li H, Handsaker B, Wysoker A, Fennell T, Ruan J, Homer N, Marth G, Abecasis G, Durbin R, Genome Project Data Processing S: The sequence alignment/ map format and SAMtools. Bioinformatics 2009, 25(16):2078-2079.

47. R Core Team: R: A Language and Environment for Statistical Computing. Vienna, Austria: R Foundation for Statistical Computing; 2012.

48. Anders S, Huber W: Differential expression analysis for sequence count data. Genome Biol 2010, 11:R106.

49. Conesa A, Gotz S, Garcia-Gomez JM, Terol J, Talon M, Robles M: Blast2GO: a universal tool for annotation, visualization and analysis in functional genomics research. Bioinformatics 2005, 21(18):3674-3676.

50. Gotz S, Garcia-Gomez JM, Terol J, Williams TD, Nagaraj SH, Nueda MJ, Robles M, Talon M, Dopazo J, Conesa A: High-throughput functional annotation and data mining with the Blast2GO suite. Nucleic Acids Res 2008, 36(10):3420-3435

51. Supek F, Bošnjak $M$, Škunca N, Šmuc T: REVIGO summarizes and visualizes long lists of gene ontology terms. PLoS One 2011, 6(7):e21800. 
52. Kawahara-Miki R, Wada K, Azuma N, Chiba S: Expression profiling without genome sequence information in a non-model species, pandalid shrimp (Pandalus latirotris), by next-generation sequencing. PLoS One 2011, 6(11):e26043.

53. Somero G, Hochachka W: Biochemical adaptation to the environment. Am Zool 1971, 11:159-167.

54. Peterson ME, Daniel RM, Danson MJ, Eisenthal R: The dependence of enzyme activity on temperature: determination and validation of parameters. Biochem J 2007, 402(2):331-337.

55. Freire $\mathrm{CA}$, Onken $\mathrm{H}, \mathrm{McNamara} \mathrm{JC}$ : A structure-function analysis of ion transport in crustacean gills and excretory organs. Comp Biochem Physiol A Mol Integr Physiol 2008, 151(3):272-304.

56. Henry RP, Lucu C, Onken H, Weihrauch D: Multiple functions of the crustacean gill: osmotic/ionic regulation, acid-base balance, ammonia excretion, and bioaccumulation of toxic metals. Front Physiol 2012, 3:431.

57. Compere P, Wanson S, Pequeux A, Gilles R, Goffinet G: Ultrastructural changes in the gill epithelium of the green crab Carcinus maenas in relation to the external salinity. Tissue Cell 1989, 21(2):299-318.

58. Newman JR, Ghaemmaghami S, Ihmels J, Breslow DK, Noble M, DeRisi JL, Weissman JS: Single-cell proteomic analysis of $\mathrm{S}$. cerevisiae reveals the architecture of biological noise. Nature 2006, 441(7095):840-846.

59. Kotlyar S, Weihrauch D, Paulsen RS, Towle DW: Expression of arginine kinase enzymatic activity and mRNA in gills of the euryhaline crabs Carcinus maenas and Callinectes sapidus. J Exp Biol 2000, 205:2395-2404.

60. Sommer MJ, Mantel LH: Effect of dopamine, cyclic AMP, and pericardial organs on sodium uptake and $\mathrm{Na} / \mathrm{K}$-ATPase activity in gills of the green crab Carcinus maenas. J Exp Zool 1988, 248:272-277.

61. Lee S, Yoon BE, Berglund K, Oh SJ, Park H, Shin HS, Augustine GJ, Lee CJ: Channel-mediated tonic GABA release from glia. Science 2010, 330(6005):790-796

62. Tsunenari T, Sun H, Williams J, Cahill H, Smallwood P, Yau KW, Nathans J: Structure-function analysis of the bestrophin family of anion channels. J Biol Chem 2003, 278(42):41114-41125.

63. Beniash E, Ivanina A, Lieb NS, Kurochkin I, Sokolova IM: Elevated level of carbon dioxide affects metabolism and shell formation in oysters Crassostrea virginica (Gmelin). Mar Ecol Prog Ser 2010, 419:95-108.

64. Acin-Perez R, Salazar E, Kamenetsky M, Buck J, Levin LR, Manfredi G: Cyclic AMP produced inside mitochondria regulates oxidative phosphorylation. Cell Metab 2009, 9(3):265-276.

65. Tresguerres M, Parks SK, Salazar E, Levin LR, Goss GG, Buck J: Bicarbonatesensing soluble adenylyl cyclase is an essential sensor for acid/base homeostasis. Proc Natl Acad Sci U S A 2010, 107(1):442-447.

66. Zippin $\mathrm{JH}$, Levin LR, Buck J: $\mathrm{CO}_{2} / \mathrm{HCO}_{3}^{-}$responsive soluble adenylyl cyclase as a putative metabolic sensor. Endocrinol Metab 2001, 12(8):366-370

67. Gopalakrishnan L, Scarpulla RC: Differential regulation of respiratory chain subunits by a CREB-dependent signal transduction pathway. J Biol Chem 1993, 269(1):105-113.

68. Wyatt GR, Kalf GF: The chemistry of insect hemolymph. J Gen Physiol 1957, 40(6):833-847.

69. Johnston MA, Davies PS: Carbohydrates of the hepatopancreas and blood tissue of Carcinus. Comp Biochem Physiol 1971, 41B:433-443.

70. Chung JS: A trehalose 6-phosphate synthase gene of the hemocytes of the blue crab, Callinectes sapidus: cloning, the expression, its enzyme activity and relationship to hemolymph trehalose levels. Saline Syst 2008, 4:18.

71. Siebers D, Lucu C, Sperling K-R, Eberlein K: Kinetics of osmoregulation in the crab Carcinus maenas. Mar Biol 1972, 17:291-303.

72. Hofmann B, Hecht H-J, Flohé L: Peroxiredoxins. Biol Chem 2002, 383:347-364

73. Premereur N, Van den Branden C, Roels F: Cytochrome P-450-dependent $\mathrm{H}_{2} \mathrm{O}_{2}$ production demonstrated in vivo. Funct Ecol 1986, 199(1):415-424.

74. Livingstone DR, Marth PG, Michel X, Narbonne JF, O'hara S, Ribera D, Winston GW: Oxyradical production as a pollution-mediated mechanism of toxicity in the common mussel, Mytilus edulis L., and other molluscs. Funct Ecol 1990, 4(3):415-424.

75. Cheng SY, Lee WC, Chen JC: Increase of uricogenesis in the kuruma shrimp Marsupenaeus japonicus reared under hyper-osmotic conditions. Comp Biochem Physiol B Biochem Mol Biol 2004, 138(3):245-253.

76. Boveris A, Oshino N, Chance B: The cellular production of hydrogen peroxide. Biochem J 1972, 128:617-630.

77. Kang BJ, Nanri T, Lee JM, Saito H, Han CH, Hatakeyama M, Saigusa M: Vitellogenesis in both sexes of gonochoristic mud shrimp, Upogebia major (Crustacea): analyses of vitellogenin gene expression and vitellogenin processing. Comp Biochem Physiol B Biochem Mol Biol 2008, 149(4):589-598.

78. Seehuus SC, Norberg K, Gimsa U, Krekling T, Amdam GV: Reproductive protein protects functionally sterile honey bee workers from oxidative stress. Proc Natl Acad Sci U S A 2006, 103(4):962-967.

79. Tomanek L, Zuzow MJ, Ivanina AV, Beniash E, Sokolova IM: Proteomic response to elevated $P \mathrm{CO}_{2}$ level in eastern oysters, Crassostrea virginica: evidence for oxidative stress. J Exp Biol 2011, 214(Pt 11):1836-1844.

80. Denicola A, Freeman BA, Trujillo M, Radi R: Peroxynitrite reaction with carbon dioxide/bicarbonate: kinetics and influence on peroxynitritemediated oxidations. Arch Biochem Biophys 1996, 333(1):49-58.

81. Livingstone DR: Contaminant-stimulated reactive oxygen species production and oxidative damage in aquatic organisms. Mar Pollut Bull 2001, 42(8):656-666

82. Dalle-Donne I, Rossi R, Milzani A, Simplicio PD, Colombo R: The actin cytoskeleton response to oxidants: from small heat shock protein phosphorilation to changes in the redox state of actin itself. Free Radic Biol Med 2001, 31(12):1624-1632.

83. Courgeon A-M, Maingourd M, Maisonhaute C, Montmory C, Rollet E, Tanguay RM, Best-Bellpomme M: Effect of hydrogen peroxide on cytoskeletal proteins of Drosophila cells: comparison with heat shock and other stressors. Exp Cell Res 1993, 204:30-37.

84. Lindquist S: The heat-shock response. Ann Rev Biochemistry 1986, 55:1151-1191.

85. Feder ME, Hofmann GE: Heat-shock proteins, molecular chaperones and the stress response: evolutionary and ecological physiology. Ann Rev Physiol 1999, 61:243-282.

86. Wickner S: Posttranslational quality control: folding, refolding, and degrading proteins. Science 1999, 286(5446):1888-1893.

87. Thomsen J, Melzner F: Moderate seawater acidification does not elicit long-term metabolic depression in the blue mussel Mytilus edulis. Mar Biol 2010, 157(12):2667-2676.

88. Hüning AK, Melzner F, Thomsen J, Gutowska MA, Krämer L, Frickenhaus S, Rosenstiel P, Pörtner H-O, Philipp EER, Lucassen M: Impacts of seawater acidification on mantle gene expression patterns of the Baltic Sea blue mussel: implications for shell formation and energy metabolism. Mar Biol 2013, 160(8):1845-1861.

89. Pörtner $\mathrm{H}-\mathrm{O}$, Reipschläger $\mathrm{A}$, Heisler $\mathrm{N}$ : Acid-base regulation, metabolism and energetics in Sipunculus nudus as a function of ambiant carbon dioxide level. J Exp Biol 1998, 201:43-55.

90. Sokolova IM, Frederich M, Bagwe R, Lannig G, Sukhotin AA: Energy homeostasis as an integrative tool for assessing limits of environmental stress tolerance in aquatic invertebrates. Mar Environ Res 2012, 79:1-15.

91. Frederich M, Pörtner H-O: Oxygen limitation of thermal tolerance defined by cardiac and ventilatory performance in spider crab, Maja squinado. Am J Physiol Regul Integr Comp Physiol 2000, 279:R1531-R1538.

92. Pörtner H-O: Climate change and temperature-dependent biogeography: oxygen limitation of thermal tolerance in animals. Naturwissenschaften 2001, 88(4):137-146.

93. Pörtner H-O: Oxygen- and capacity-limitation of thermal tolerance: a matrix for integrating climate-related stressor effects in marine ecosystems. J Exp Biol 2010, 213(6):881-893.

94. Kooijman SALM: Dynamic Energy Budget Theory for Metabolic Organisation, Volume 3. Cambridge, United Kingdom: Cambridge University Press; 2010.

95. Pörtner H-O, Farrell AP: Physiology and climate change. Science 2008, 322:690-692.

\section{doi:10.1186/1471-2164-15-789}

Cite this article as: Harms et al:: Gene expression profiling in gills of the great spider crab Hyas araneus in response to ocean acidification and warming. BMC Genomics 2014 15:789. 